\title{
Sources and mixing state of size-resolved elemental carbon particles in a European megacity: Paris
}

\author{
R. M. Healy ${ }^{1}$, J. Sciare ${ }^{2}$, L. Poulain ${ }^{3}$, K. Kamili ${ }^{3}$, M. Merkel $^{3}$, T. Müller ${ }^{3}$, A. Wiedensohler ${ }^{3}$, S. Eckhardt ${ }^{4}$, A. Stohl ${ }^{4}$, \\ R. Sarda-Estève ${ }^{2}$, E. McGillicuddy ${ }^{1}$, I. P. O'Connor ${ }^{1}$, J. R. Sodeau ${ }^{1}$, and J. C. Wenger $^{1}$ \\ ${ }^{1}$ Department of Chemistry and Environmental Research Institute, University College Cork, Ireland \\ ${ }^{2}$ LSCE, CEA-CNRS-UVSQ, UMR1572 Laboratoire des Sciences du Climat et de l'Environnement, \\ Gif-sur-Yvette, France \\ ${ }^{3}$ Leibniz Institute for Tropospheric Research, Leipzig, Germany \\ ${ }^{4}$ Norsk Institutt for Luftforskning, Kjeller, Norway
}

Correspondence to: R. M. Healy (robert.healy@ucc.ie)

Received: 9 August 2011 - Published in Atmos. Chem. Phys. Discuss.: 9 November 2011

Revised: 1 February 2012 - Accepted: 4 February 2012 - Published: 15 February 2012

\begin{abstract}
An Aerosol Time-Of-Flight Mass Spectrometer (ATOFMS) was deployed to investigate the size-resolved chemical composition of single particles at an urban background site in Paris, France, as part of the MEGAPOLI winter campaign in January/February 2010. ATOFMS particle counts were scaled to match coincident Twin Differential Mobility Particle Sizer (TDMPS) data in order to generate hourly size-resolved mass concentrations for the single particle classes observed. The total scaled ATOFMS particle mass concentration in the size range $150-1067 \mathrm{~nm}$ was found to agree very well with the sum of concurrent High-Resolution Time-of-Flight Aerosol Mass Spectrometer (HR-ToF-AMS) and Multi-Angle Absorption Photometer (MAAP) mass concentration measurements of organic carbon (OC), inorganic ions and black carbon $(\mathrm{BC})\left(R^{2}=0.91\right)$. Clustering analysis of the ATOFMS single particle mass spectra allowed the separation of elemental carbon (EC) particles into four classes: (i) EC attributed to biomass burning (ECbiomass), (ii) EC attributed to traffic (ECtraffic), (iii) EC internally mixed with $\mathrm{OC}$ and ammonium sulfate $\left(\mathrm{ECOCSO}_{\mathrm{x}}\right)$, and (iv) EC internally mixed with $\mathrm{OC}$ and ammonium nitrate $\left(\mathrm{ECOCNO}_{\mathrm{x}}\right)$. Average hourly mass concentrations for ECcontaining particles detected by the ATOFMS were found to agree reasonably well with semi-continuous quantitative thermal/optical EC and optical BC measurements $\left(r^{2}=0.61\right.$ and $0.65-0.68$ respectively, $n=552$ ). The EC particle mass assigned to fossil fuel and biomass burning sources also agreed reasonably well with $\mathrm{BC}$ mass fractions assigned to
\end{abstract}

the same sources using seven-wavelength aethalometer data $\left(r^{2}=0.60\right.$ and 0.48 , respectively, $\left.n=568\right)$. Agreement between the ATOFMS and other instrumentation improved noticeably when a period influenced by significantly aged, internally mixed EC particles was removed from the intercomparison. $88 \%$ and $12 \%$ of EC particle mass was apportioned to fossil fuel and biomass burning respectively using the ATOFMS data compared with $85 \%$ and $15 \%$ respectively for $\mathrm{BC}$ estimated from the aethalometer model. On average, the mass size distribution for EC particles is bimodal; the smaller mode is attributed to locally emitted, mostly externally mixed EC particles, while the larger mode is dominated by aged, internally mixed $\mathrm{ECOCNO}_{\mathrm{x}}$ particles associated with continental transport events. Periods of continental influence were identified using the Lagrangian Particle Dispersion Model (LPDM) "FLEXPART". A consistent minimum between the two EC mass size modes was observed at approximately $400 \mathrm{~nm}$ for the measurement period. EC particles below this size are attributed to local emissions using chemical mixing state information and contribute $79 \%$ of the scaled ATOFMS EC particle mass, while particles above this size are attributed to continental transport events and contribute $21 \%$ of the EC particle mass. These results clearly demonstrate the potential benefit of monitoring size-resolved mass concentrations for the separation of local and continental EC emissions. Knowledge of the relative input of these emissions is essential for assessing the effectiveness of local abatement strategies. 


\section{Introduction}

Airborne particulate matter (PM) impacts significantly upon air quality and climate. The surface area and oxidative potential of ultrafine particles $(<100 \mathrm{~nm}$ diameter) both play a role in inducing chronic pulmonary inflammation (Maier et al., 2008). Aerosol particles in the accumulation and coarse modes alter the radiative balance of the Earth-atmosphere system directly by absorbing and scattering incoming radiation and indirectly by altering the microphysical properties of clouds (Solomon et al., 2007). In urban environments, submicrometer aerosol is typically apportioned to primary sources including vehicular, biomass burning, and industrial emissions, although formation of secondary aerosol through atmospheric processing of primary emissions can be equally important. A recent study collating data from several urban sites around Europe estimates that between 3-24\% of the mass of particulate matter smaller than $10 \mu \mathrm{m}$ in diameter $\left(\mathrm{PM}_{10}\right)$ is composed of black carbon $(\mathrm{BC})$ (Reche et al., 2011), the light absorbing form of carbonaceous material, commonly referred to as soot (Horvath, 1993; Han et al., 2007, 2010). BC causes positive radiative forcing (RF) through absorption and, if internally mixed, is estimated to be the second most important contributor to global warming through direct forcing after $\mathrm{CO}_{2}$ (Jacobson, 2001). Reducing emissions of $\mathrm{BC}$ has been identified as a potential means for decision makers to simultaneously mitigate against global warming and poor air quality due to its relatively short atmospheric lifetime (UNEP, 2011). The positive RF of BC can be enhanced when $\mathrm{BC}$ is internally mixed with species that scatter light such as organic carbon (OC) and inorganic salts, the mixing state best described as a "core-shell" arrangement (Jacobson, 2001; Moffet and Prather, 2009). However, any increase in positive RF for aged $\mathrm{BC}$, arising from enhanced scattering, is also offset by increased hygroscopicity and thus reduced atmospheric lifetime due to wet deposition in humid environments (Stier et al., 2006; Moffet and Prather, 2009).

Identifying the sources of $\mathrm{BC}$ in urban environments is important from an air quality perspective. Discrimination between fossil fuel and biomass burning $\mathrm{BC}$ as well as local and continental $\mathrm{BC}$ in these environments will be relevant for effective assessment of local abatement strategies such as the EU Low Emission Zones (http://lowemissionzones.eu). These zones are implemented to reduce local emissions of nitrogen oxides and PM associated with vehicular traffic. Thus knowledge of the relative impact of other sources, including domestic wood burning, will be essential for assessing their efficacy.

Air quality reduction arising from elevated aerosol mass concentrations is of particular concern in highly populated megacities such as Mexico City and Beijing (Querol et al., 2008; Yang et al., 2005), representing a significant health risk (Gurjar et al., 2010). Apart from London, Greater Paris is the only city in the European Union that qualifies as a megacity, with a population of approximately 10 million inhabitants.
The urbanised Paris area is quite dense (approximately $20 \mathrm{~km}$ across), is surrounded by flat terrain and is also relatively far from other European cities. Two measurement campaigns were carried out in Paris in summer 2009 and winter 2010 as part of the collaborative project entitled Megacities: Emissions, urban, regional and Global Atmospheric POLlution and climate effects, and Integrated tools for assessment and mitigation (MEGAPOLI). Despite a high population density, detailed gas phase measurements, physical and chemical aerosol measurements and source apportionment for the Paris region are relatively sparse (Ruellan and Cachier, 2001; Gros et al., 2007; Favez et al., 2007, 2009; Sciare et al., 2010, 2011).

A recent study by Sciare et al. (2010) highlighted the significant influence of air mass origin on particle mass concentrations in Paris. Interestingly, the highest $\mathrm{PM}_{2.5}$ mass concentrations, up to $70 \mu \mathrm{g} \mathrm{m}^{-3}$, were observed when continental air masses passed over North-Western Europe before arriving in Paris. $\mathrm{PM}_{2.5}$ composition during these periods was dominated by ammonium nitrate and ammonium sulfate, comprising approximately $75 \%$ of the $\mathrm{PM}_{2.5}$ mass. During periods influenced by clean marine air masses, $\mathrm{PM}_{2.5}$ mass concentrations were typically lower than $15 \mu \mathrm{g} \mathrm{m}^{-3}$, and composition was dominated by carbonaceous material. These findings indicate that continental emissions can contribute to exceedances of the EU recommended limit value of $25 \mathrm{\mu g} \mathrm{m}^{-3}$, and impact upon air quality in Paris. Thus the effective separation of local and continental input will be necessary when considering abatement strategies to reduce ambient levels of $\mathrm{PM}_{2.5}$.

Estimating the relative source inputs for individual PM components such as $\mathrm{BC}$ can be quite difficult, requiring advanced measurement techniques with high temporal resolution. The single-particle soot photometer (SP2) provides size-resolved information on single BC particles, and can determine whether these particles are coated or uncoated (Gao et al., 2007; Slowik et al., 2007). However, the chemical composition of the coatings cannot be directly measured. Seven-wavelength (7- $\lambda$ ) aethalometer measurements have recently been employed to tentatively separate the biomass burning and fossil fuel contributions to measured BC mass concentrations (Sandradewi et al., 2008a; Herich et al., 2010; Favez et al., 2010; Sciare et al., 2011), but local and transported contributions cannot be separated using this method alone. Ultimately, size-resolved BC mass concentration data with high temporal resolution coupled with internal mixing state information are required to effectively identify and separate BC particles of local and continental origin.

Single particle mass spectrometers, such as the aerosol time-of-flight mass spectrometer (ATOFMS) can provide information on the size-resolved chemical composition and internal mixing state of carbonaceous particles (Sullivan and Prather, 2005). However, because these instruments use mass spectrometry rather than light absorption as the method of detection, the refractory carbon detected is typically referred 
to as EC. EC-containing particles arising from different sources are often characterised by unique internal mixing states, and thus can be apportioned using single particle mass spectra coupled with meteorological data (Reinard et al., 2007; Moffet et al., 2008a; Snyder et al., 2009; Healy et al., 2010). Aerosol mass concentrations can also be reconstructed successfully when particle counts from single particle mass spectrometers are scaled to coincident data from colocated particle counting instruments (Wenzel et al., 2003; Qin et al., 2006). Despite associated matrix effects, advances have also been made in quantifying individual chemical species using single particle mass spectra either through multivariate analysis or by using intensities for specific ions (Fergenson et al., 2001; Pratt et al., 2009a; Froyd et al., 2010; Jeong et al., 2011).

The aim of this study was to estimate the relative importance of fossil fuel and biomass burning sources on ambient concentrations of EC-containing particles in Paris using ATOFMS size-resolved chemical data. The methodology described here represents a relatively straightforward approach to EC particle mass reconstruction and source apportionment. Periods influenced by continental transport were confirmed using an advanced atmospheric transport model (FLEXPART) (Stohl et al., 2005). The reconstruction of EC particle mass concentrations from ATOFMS data, and the separation of relative contributions to EC from fossil fuel and biomass burning sources were validated using $\mathrm{EC}$ and $\mathrm{BC}$ mass concentrations obtained using a variety of other instruments.

\section{Methodology}

\subsection{Sampling site and instrumentation}

Measurements were performed from 15 January-11 February 2010 at the Laboratoire d'Hygiène de la Ville de Paris (LHVP), Paris ( $\left.48.75^{\circ} \mathrm{N}, 2.36^{\circ} \mathrm{E}\right)$; an urban background site, described in more detail elsewhere (Favez et al., 2007; Sciare et al., 2010). An ATOFMS (Gard et al., 1997) (TSI model 3800) fitted with an aerodynamic lens (TSI model AFL100) was used to measure the size-resolved chemical composition of single particles in the size range 100-3000 nm (vacuum aerodynamic diameter, $d_{\mathrm{va}}$ ). In brief, single particles are sampled through a critical orifice and focused into a tight beam in the aerodynamic lens before transmission to the sizing region. Here, $d_{\mathrm{va}}$ for each particle is calculated based on its time-of-flight between two orthogonally positioned continuous wave lasers (Nd:YAG, $532 \mathrm{~nm}$ ). Particles then arrive at the mass spectrometry region of the instrument and are ionised using a Nd:YAG laser $(266 \mathrm{~nm})$. The resulting positive and negative ions are analysed using two collinear timeof-flight mass spectrometers. Dual ion mass spectra were subsequently clustered into classes as described in the next section. Particles were sampled through a stainless steel line at a height of approximately $4 \mathrm{~m}$ above ground level.

A suite of instrumentation for the characterization of the physico-chemical properties of particles was also located in a separate container adjacent to the ATOFMS. The instruments included a High Resolution Time-of-Flight Aerosol Mass Spectrometer (HR-ToF-AMS, Aerodyne Research Inc.) (DeCarlo et al., 2006), a Twin Differential Mobility Particle Sizer (TDMPS) (Birmili et al., 1999), a Multi-Angle Absorption Photometer (MAAP, Model 5012, Thermo Scientific) (Petzold and Schönlinner, 2004) and a three wavelength nephelometer (TSI Model 3563) (Heintzenberg et al., 2006). A collection efficiency of 0.4 was calculated for the HRToF-AMS based on comparison with concurrent TDMPS and particle-into-liquid sampler (PILS) data. All instruments were connected to the same sampling system consisting of a low flow $\mathrm{PM}_{10}$ inlet located approximately $6 \mathrm{~m}$ above ground level directly followed by an automatic aerosol diffusion dryer system maintaining the relative humidity in the line below $30 \%$ (Tuch et al., 2009).

$\mathrm{PM}_{2.5}$ was also sampled on the roof of the LHVP building (14 $\mathrm{m}$ above ground level) and analysed using an OCEC field instrument (Sunset Laboratory, Forest Grove, OR) (Bae et al., 2004) and a 7- $\lambda$ aethalometer (Magee Scientific, model AE-31, discussed below). The OCEC analyser was operated at $81 \mathrm{~min}^{-1}$ and provides semi-continuous hourly concentrations of OC and EC. A denuder was placed upstream in order to minimise VOC adsorption artefacts. Measurement uncertainty for this instrument is poorly described in the literature and thus an estimate of $20 \%$ is assumed here (Peltier et al., 2007).

A Tapered Element Oscillating Microbalance (TEOM, $\mathrm{R} \& \mathrm{P}$ ) fitted with a Sample Equilibriation System (SES) and a Filter Dynamic Measurement System (FDMS, model 8500) was also located on the roof of the LHVP building and was used to measure mass concentrations of $\mathrm{PM}_{2.5}$ (Grover et al., 2005; Sciare et al., 2007). This system enables the measurement of semi-volatile material (SVM) in $\mathrm{PM}_{2.5}$, typically dominated by ammonium nitrate in Paris during the winter months (Favez et al., 2007). A mean concentration of $21.1 \mu \mathrm{g} \mathrm{m}^{-3}$ was calculated for the measurement period which is close to the yearly average of $\sim 20 \mu \mathrm{g} \mathrm{m}^{-3}$ for the Paris background atmosphere calculated from local air quality network data (AIRPARIF, http://www.airparif. asso.fr/).

Meteorological data were collected using a Campbell Scientific weather station. Additional meteorological data was also provided by Météo-France, collected at Parc Montsouris $\left(48.82^{\circ} \mathrm{N}, 2.34^{\circ} \mathrm{E}, 75 \mathrm{~m}\right.$ a.s.l.), approximately $1.5 \mathrm{~km}$ from LHVP.

\subsection{ATOFMS data analysis and scaling procedures}

The ATOFMS collected approximately 1.75 million single particle mass spectra from 15 January-11 February 2010. 
These spectra were imported into ENCHILADA, a freeware data analysis software package (Gross et al., 2010), and clustered using the $K$-means algorithm as described in detail elsewhere (Healy et al., 2009, 2010). A $K$ value of 80 was chosen to create the initial clusters, but these were merged (or clustered again if found to be inhomogeneous) to produce around 15 final particle classes, which are broadly similar to those regularly observed in other urban ATOFMS field studies (Dall'Osto and Harrison, 2006; Moffet et al., 2008a; Shields et al., 2008; Eatough et al., 2008; Dall'Osto et al., 2009b; Healy et al., 2010; Jeong et al., 2011). Four of the classes were assigned as EC-containing particles.

Due to size-dependent transmission efficiencies of particles through the aerodynamic lens and sizing region, limited light scattering for smaller particles, and instrument busytime during data acquisition, quantitative ambient particle number concentrations are very difficult to achieve using the ATOFMS alone (Pratt et al., 2009b). In order to produce meaningful temporal trends for the ATOFMS classes, it is advisable to scale the total ATOFMS counts using a quantitative particle counting instrument, such as an optical particle counter (Allen et al., 2000), scanning mobility particle sizer (SMPS) (Bein et al., 2006; Reinard et al., 2007) or aerodynamic particle sizer (APS) (Qin et al., 2006).

Size distributions from the TDMPS have been used to scale the ATOFMS counts at a temporal resolution of $1 \mathrm{~h}$. The ATOFMS counts represent particles that were both sized and successfully ionised to produce mass spectra. It is also assumed that all particles were ionised with the same efficiency. This may introduce error in the scaled counts for the different particle classes, as different detection efficiencies are observed for particles of differing composition (Kane et al., 2001; Wenzel et al., 2003; Gross et al., 2006). Nonspherical particles such as fractal soot are also more susceptible to divergence from the particle beam due to perpendicular drag forces, and thus may be detected less efficiently than spherical particle types (Moffet and Prather, 2009).

The TDMPS system determines the number size distribution in the size range 3-800 $\mathrm{nm}$ (electrical mobility diameter, $d_{\mathrm{m}}$ ) while the ATOFMS measures $d_{\mathrm{va}}$ in the range 100$3000 \mathrm{~nm}$. Here, when converting from particle number to volume, it has been assumed that all particles are spherical, no internal voids exist and $d_{\mathrm{m}}$ is thus equal to the particle volume equivalent diameter $\left(d_{\mathrm{ve}}\right)$. A conversion of the ATOFMS $d_{\mathrm{va}}$ data to $d_{\mathrm{ve}}$ is necessary in order to compare particle counts. Assuming all particles are spherical, $d_{\mathrm{va}}$ can be related to $d_{\mathrm{ve}}$ as follows:

$d_{\mathrm{va}}=\frac{\rho_{\mathrm{p}}}{\rho_{0}} \frac{d_{\mathrm{ve}}}{\chi}$

where $\rho_{\mathrm{p}}$ is the particle density, $\rho_{0}$ is standard density $\left(1 \mathrm{~g} \mathrm{~cm}^{-3}\right)$ and $\chi$ is the dynamic shape factor (assumed to be 1 ). This is a highly simplified version of particle diameter, morphology and density relationships that are covered in much greater detail elsewhere (DeCarlo et al., 2004). Knowl- edge of the particle density is required for this conversion, and this was estimated based on the mass concentration measurements from the HR-ToF-AMS and the MAAP. An average estimated density of $1.49 \pm 0.07 \mathrm{~g} \mathrm{~cm}^{-3}(1 \sigma)$ was observed for the entire sampling period. Thus, a single density value of $1.5 \mathrm{~g} \mathrm{~cm}^{-3}$ was chosen to convert the ATOFMS $d_{\mathrm{va}}$ data to $d_{\mathrm{m}}$ before scaling the ATOFMS counts to the TDMPS number-size distributions. 8 size bins were used for the scaling procedure, created by merging adjacent pairs of TDMPS bins, covering a dm size range of $100-712 \mathrm{~nm}$ (or $\left.150-1067 \mathrm{~nm}, d_{\mathrm{va}}\right)$. Thus the ATOFMS results are focused on $\mathrm{PM}_{1}$ and not $\mathrm{PM}_{2.5}$. ATOFMS mass concentrations were calculated from the scaled counts assuming particle sphericity (Reinard et al., 2007). A single density assumption is known to be incorrect due to differing particle compositions, and fresh soot particles can exhibit several size-dependent effective densities (Maricq and Xu, 2004; Spencer and Prather, 2006). Nevertheless, the use of a single density for ATOFMS scaling has previously resulted in satisfactory PM mass reconstruction when compared to MOUDI and beta attenuation monitor data (Qin et al., 2006). The size-dependent scaling factors are shown in Fig. S1, and described in more detail in the Supplement. The effect of varying the assumed particle density is also included in the Supplement. The scaling factors are similar to those expected based on the shape of the particle transmission efficiency curve for the AFL-100 aerodynamic lens (Wang and McMurry, 2006; Jeong et al., 2011). A comparison of the total scaled hourly ATOFMS mass concentration and sum of the HR-ToF-AMS total non-refractory mass concentration (ammonium + nitrate + sulfate + non-sea salt chloride + organics) and MAAP BC mass concentration is given in Fig. S2. The level of agreement is very good $\left(r^{2}=0.91\right.$, slope $\left.=1.14\right)$ considering that the HR-ToF-AMS does not detect refractory material such as sea salt and dust. The agreement between the scaled ATOFMS mass concentration and coincident FDMS-TEOM PM P.5 $_{2.5}$ mass concentration was also very good $\left(r^{2}=0.95\right.$, slope $\left.=1.62\right)$, although the slope is higher as expected considering the different size ranges (Fig. S2).

One aspect of the quantification approach used here is that it provides mass concentrations for single particle classes rather than individual chemical species. The total scaled ATOFMS EC particle mass reported below could be more accurately described as "EC-containing particle mass", and will include contributions from any secondary species, such as organic carbon and inorganic ions, that are internally mixed with EC. Therefore the reconstructed ATOFMS EC particle mass is expected to be higher than the EC and BC mass concentrations provided by the other instruments, especially during periods influenced by aged, internally mixed EC particles. This is discussed in detail in Sect. 3.3. 


\subsection{Aethalometer instruments and model}

Aerosol absorption coefficients $\left(b_{\mathrm{abs}}\right)$ for $\mathrm{PM}_{2.5}$ were obtained every $5 \mathrm{~min}$ at seven different wavelengths $(370,470$, 520, 590, 660, 880 and $950 \mathrm{~nm})$ using a Magee Scientific aethalometer (model AE-31) fitted with a cyclone with a $50 \%$ cut-off diameter at $2.5 \mu \mathrm{m}$ ( $\mathrm{R} \& \mathrm{P}$, Albany, NY). This instrument was operating at a flow rate of $51 \mathrm{~min}^{-1}$ in an automated mode, under which the filter tape advances when the attenuation (ATN) at $370 \mathrm{~nm}$ reaches 100 . For a 12 day period (5-17 February), a second identical $7-\lambda$ aethalometer (model AE-31) was operated in parallel and equipped with a size selective inlet impactor (PCIS, SKC Inc.) removing particles with da larger than $0.25 \mu \mathrm{m}$ using a flow rate of $91 \mathrm{~min}^{-1}$. Thus quasi ultra-fine BC $\left(d_{\mathrm{a}}<0.25 \mu \mathrm{m}\right)$ was obtained every $5 \mathrm{~min}$ for this period. Absorption coefficients directly obtained from these two instruments are affected by various sampling and analytical artefacts (multiple scattering and shadowing effects) which must be accounted for (Collaud Coen et al., 2010). The correction procedure introduced by Weingartner et al. (2003) was applied to the 2 datasets as follows:

$b_{\text {abs }, \lambda, \mathrm{t}}=b_{\text {aeth }, \lambda, \mathrm{t}} /\left(2.14 \times \mathrm{R}(\mathrm{ATN})_{\lambda, t}\right)$

Where, at a given time $(t)$ and a given wavelength $(\lambda), b_{\mathrm{abs}, \lambda, \mathrm{t}}$ and $b_{\text {aeth }, \lambda, t}$ are the corrected absorption coefficient and the raw absorption coefficient, respectively. The constant (2.14) represents the multiple scattering of the light beam at the filter fibres in the unloaded filter. Finally, R(ATN $)_{\lambda, t}$ describes the decrease of the latter artefact with gradual accumulation of particles on/in the filter, thus correcting for the shadowing effect. $\mathrm{R}(\mathrm{ATN})_{\lambda, t}$ was determined following the equation:

$\mathrm{R}(\mathrm{ATN})_{\lambda, t}=\left(\frac{1}{f_{\lambda}}-1\right) \times \frac{\ln \left(\mathrm{ATN}_{\lambda, t}\right)-\ln (10)}{\ln (50)-\ln (10)}+1$

where $\operatorname{ATN}_{\lambda, t}$ corresponds to the light attenuation measured by the aethalometer at a given time $(t)$ and a given wavelength $(\lambda)$, and $f_{\lambda}$ allows for the correction of the instrumental error that occurs when the shadowing effect is disregarded. The latter parameter was determined by keeping the median ratio of absorption coefficients (before and after the change of each filter spot) closest to 1 . The factors $f \lambda$ were found to range from 1.085 (at $950 \mathrm{~nm}$ ) to 1.179 (at $370 \mathrm{~nm}$ ). These factors were compared with those obtained from a similar aethalometer instrument running at the suburban SIRTA site $\left(48.71^{\circ} \mathrm{N}, 2.02^{\circ} \mathrm{E}\right.$, approximately $20 \mathrm{~km} \mathrm{SW}$ of the LHVP site) during the MEGAPOLI campaign, exhibiting very good consistency (slope of 1.00: $r^{2}=0.87 ; n=7$ ). The terms $\ln (10)$ and $\ln (50)$ use the filter loading corrections provided by Weingartner et al. (2003) of ATN of $10 \%$ as a reference point (characteristic of unloaded filter spots). Note also that the $b_{\text {abs }}$ corrections applied here (Weingartner et al., 2003) represent the best possible corrections in the absence of light scattering coefficient measurements (Collaud Coen et al., 2010).
In this study, equivalent black carbon (EBC) mass concentrations for $\mathrm{PM}_{2.5}$ were obtained from hourly $b_{\mathrm{abs}, 950 \mathrm{~nm}}$ determined by the aethalometer and a specific mass absorption efficency (MAE) determined using EC mass concentrations measured in parallel every hour by the OCEC Sunset field instrument. A specific mass absorption efficiency at $950 \mathrm{~nm}\left(\right.$ MAE $\left._{950 \mathrm{~nm}}\right)$ of $(5.08 \pm 0.03) \mathrm{m}^{2} \mathrm{~g}^{-1}$ was then obtained from this linear regression $\left(r^{2}=0.91, n=782\right)$ and was used here to estimate BC concentrations $\left(d_{\mathrm{a}}<2.5 \mu \mathrm{m}\right)$ every $5 \mathrm{~min}$ from the $b_{\text {abs, } 950 \mathrm{~nm}} \mathrm{PM}_{2.5}$ dataset. This MAE $950 \mathrm{~nm}$ value was also used to derive quasi ultra-fine $\left(d_{\mathrm{a}}<0.25 \mu \mathrm{m}\right)$ $\mathrm{BC}$ concentrations every $5 \mathrm{~min}$ from the ultra-fine $b_{\mathrm{abs}, 950 \mathrm{~nm}}$ dataset. An intercomparison between the 2 aethalometers for $\mathrm{BC}<2.5 \mu \mathrm{m}$ for the period 5-7 February 2010 (hourly averages) resulted in very good agreement $\left(r^{2}=0.99, n=37\right)$ with a slope close to one (0.99).

Recent studies have shown that information delivered by multi-wavelength aethalometers can be used in a more quantitative way, in conjunction with complementary carbon measurements, to provide source apportionment of domestic wood-burning aerosols because carbonaceous aerosols have both modern (biomass burning, domestic wood combustion) and fossil fuel origins (Sandradewi et al., 2008a; Favez et al., 2009, 2010; Sciare et al., 2011). The source apportionment performed by the aethalometer model (Sandradewi et al., 2008a) is based on the strong spectral dependence of light absorption properties of brown carbon aerosols (Hoffer et al., 2006 and references therein), which are present in ambient biomass burning aerosols (Jeong et al., 2008; Sandradewi et al., 2008b; Yang et al., 2009). The model subsequently relies on the different Angström Absorption Exponents for fossil fuel and biomass burning to derive, at an hourly temporal resolution, concentrations of $\mathrm{BC}$ apportioned to fossil fuel $\left(\mathrm{BC}_{\mathrm{ff}}\right)$ and biomass burning $\left(\mathrm{BC}_{\mathrm{bb}}\right)$ derived using the following aethalometer model equations:

$b_{\mathrm{abs}, \lambda}=b_{\mathrm{abs}, \mathrm{ff}, \lambda}+b_{\mathrm{abs}, \mathrm{bb}, \lambda}$

$\left(b_{\mathrm{abs}, \mathrm{ff}, 470 \mathrm{~nm}} / b_{\mathrm{abs}, \mathrm{ff}, 950 \mathrm{~nm}}\right)=(470 / 950)^{-\alpha \mathrm{ff}}$

$\left(b_{\mathrm{abs}, \mathrm{bb}, 470 \mathrm{~nm}} / b_{\mathrm{abs}, \mathrm{bb}, 950 \mathrm{~nm}}\right)=(470 / 950)^{-\alpha \mathrm{bb}}$

$\mathrm{BC}_{\mathrm{ff}}=b_{\mathrm{abs}, \mathrm{ff}, 950 \mathrm{~nm} / \mathrm{MAE}_{950} \mathrm{~nm}}$

$\mathrm{BC}=\mathrm{BC}_{\mathrm{ff}}+\mathrm{BC}_{\mathrm{bb}}$

where $b_{\mathrm{abs}, \mathrm{ff}, \mathrm{Xnm}}$ stands for the absorption coefficient of fos-

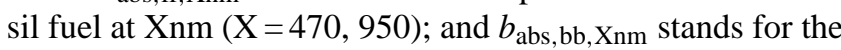
absorption coefficient of biomass burning at Xnm (X $=470$, 950). In Eqs. (5) and (6), $\alpha_{\mathrm{ff}}$ and $\alpha_{\mathrm{bb}}$ represent the Angstrom absorption exponents of fossil fuel and wood burning, respectively. In this study, values of 1.0 and 2.0 were used for $\alpha_{\mathrm{ff}}$ and $\alpha_{\mathrm{bb}}$ respectively, based on values previously reported for fossil fuel and wood burning aerosols (Clarke et al., 2007; 

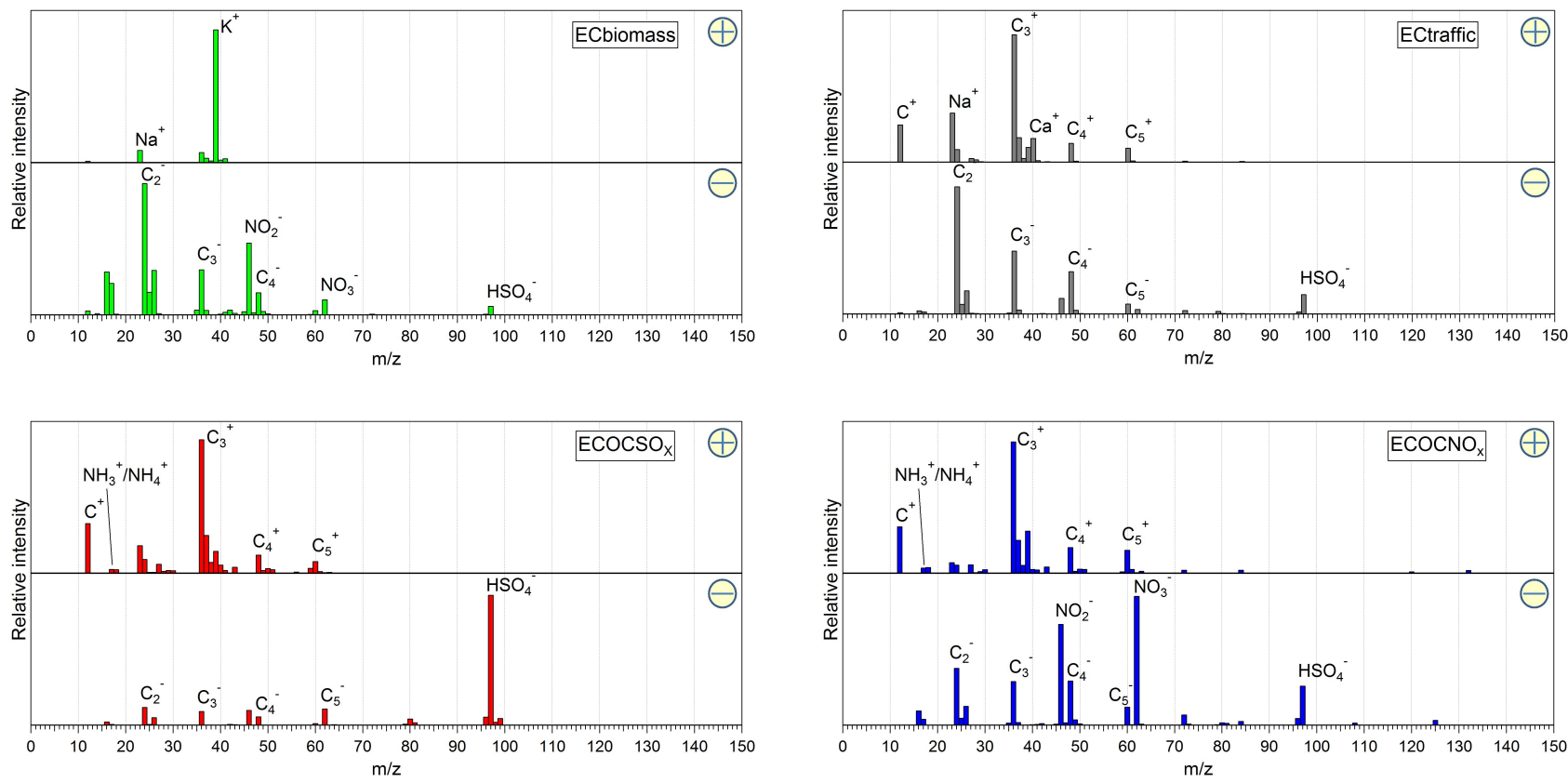

Fig. 1. Average dual ion mass spectra for the ATOFMS EC classes.
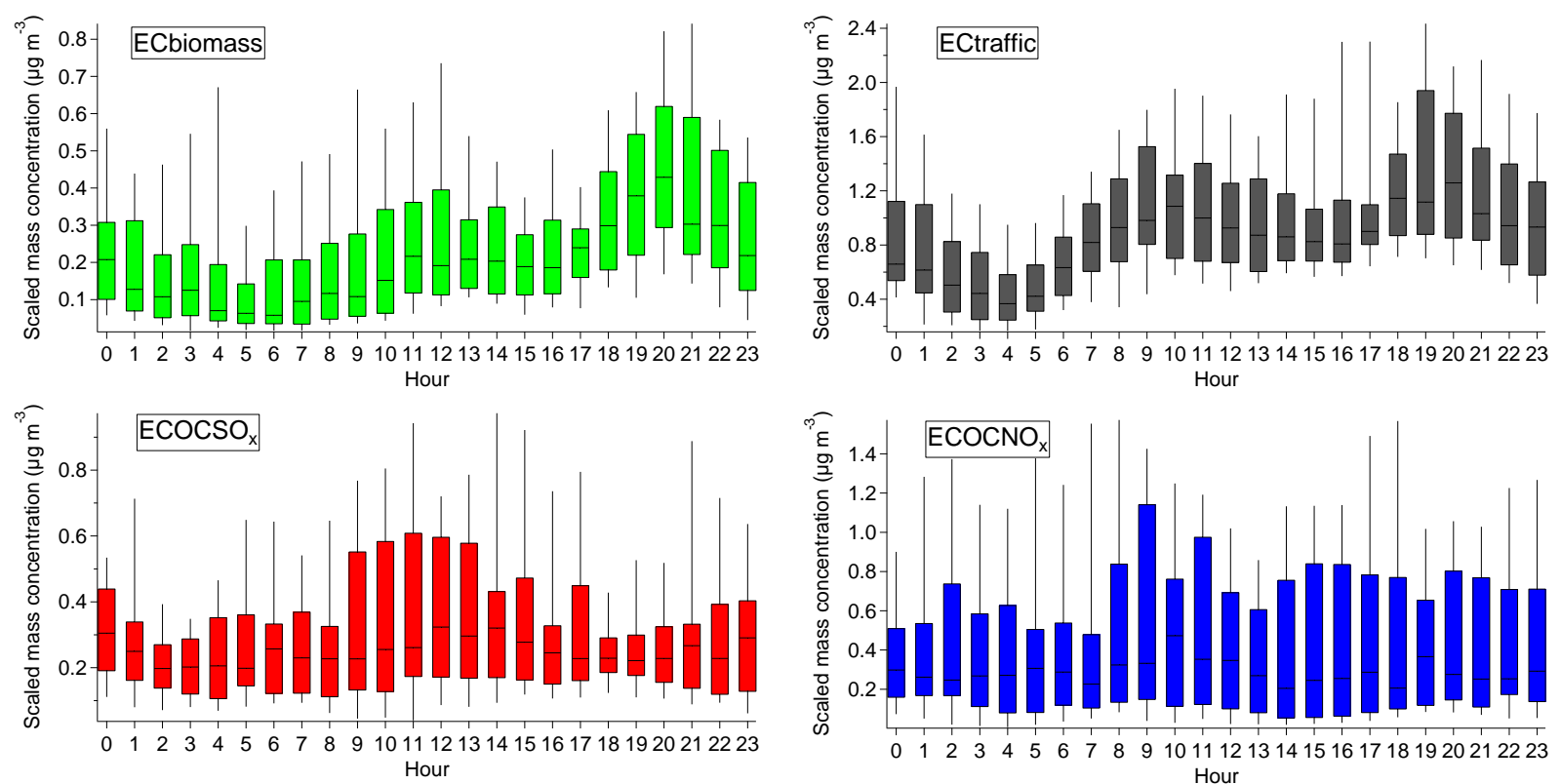

Fig. 2. Box plots of diurnal trends (local time) of scaled mass concentration for the 4 ATOFMS EC classes $(n=27)$. Median, 75 th percentile and 90th percentile are denoted by the solid line, box and whisker respectively.

Lewis et al., 2008) and used by Sandradewi et al. (2008) and Favez et al. (2010). This calculation was performed for both aethalometer datasets. Further details of the aethalometer model, and associated assumptions, can be found in Sciare et al. (2011).

\subsection{Lagrangian Particle Dispersion Model retroplumes}

The FLEXPART (version 8.2) backward-running Lagrangian Particle Dispersion Model (LPDM) (Stohl et al., 2005) was run using meteorological data from the ECMWF model $(1 \times 1$ degree global resolution, $0.18 \times 0.18$ degree nested resolution for Europe). FLEXPART allowed an accurate 
assignment of air masses associated with aerosol transport events by accounting for turbulence and convection processes which are particularly important at low altitudes and ignored by trajectory models (Stohl et al., 2002). In brief, 60000 theoretical particles were released from a small box at the receptor location and followed backward in time for 20 days. In this work an aerosol tracer was used, subject to washout and dry deposition processes using values appropriate for sulfate aerosol. The model was initialized every $3 \mathrm{~h}$ and particles were released at a uniform rate over a $3 \mathrm{~h}$ period, between heights of 10 and $30 \mathrm{~m}$ in this case. The ensemble of particles released formed a so-called "retroplume" backwards in time. The model outputted 3-dimensional potential emission sensitivity (PES) distribution at a $3 \mathrm{~h}$ resolution. These PES plots demonstrated the residence time of the particle ensemble in different geographical regions, and helped to identify regions where the ensemble would be exposed to any theoretical ground level emissions. Most emissions occur at ground level and therefore high PES values in the lowest model layer $(50 \mathrm{~m})$ were most important when considering transported aerosol input. Graphically, the output of this "footprint" PES was very useful as it described the times when air masses were most susceptible to ground level emissions (units of $\mathrm{ns} \mathrm{kg}^{-1}$ ). Thus, potential aerosol source regions could be identified, and their relative contributions could be estimated. Examples of this output are provided and discussed in Sect. 3.2.

\section{Results and discussion}

\subsection{ATOFMS EC classes}

4 of the 15 ATOFMS classes identified were assigned as EC-containing. One class is assigned to biomass burning (ECbiomass), and three classes are assigned to fossil fuel combustion (ECtraffic, $\mathrm{ECOCSO}_{\mathrm{x}}$ and $\mathrm{ECOCNO}_{\mathrm{x}}$ ). Average mass spectra, box-plots of diurnal trends, and average mass size distributions for the four EC particle classes are shown in Figs. 1, 2 and 3 respectively.

\subsubsection{EC attributed to biomass burning (ECbiomass)}

ECbiomass particles are characterised by an intense signal for potassium $[\mathrm{K}]^{+}$and a relatively smaller signal for sodium $[\mathrm{Na}]^{+}$in the positive ion mass spectra, and elemental carbon fragments $\left[\mathrm{C}_{\mathrm{n}}\right]^{-}$in the negative ion mass spectra (Fig. 1). A relatively low signal is also observed for nitrate $\left[\mathrm{NO}_{2}\right]^{-},\left[\mathrm{NO}_{3}\right]^{-}$. ECbiomass particles consistently peak in the evening, typically around 20:00 (local time), suggesting a local domestic wood-burning source (Fig. 2). Very similar mass spectra have been assigned to fresh domestic solid fuel burning emissions in Cork Harbour, Ireland (Healy et al., 2010). Potassium-containing soot is a well-established tracer for biomass combustion (Andreae, 1983; Soto-García et al., 2011). Potassium-rich elemental carbon single particle

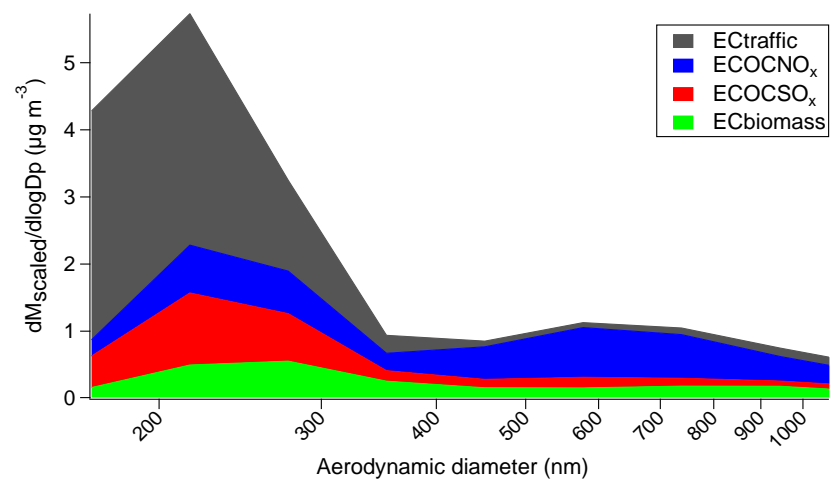

Fig. 3. Average scaled mass size distributions (stacked) for the 4 ATOFMS EC classes for the entire measurement period. The total corresponds to the average size-resolved scaled EC mass concentration.

mass spectra have been previously observed in several urban field studies and assigned to a biomass burning source, for example (Moffet et al., 2008a; Bi et al., 2011). However, a more confident assignment can be made for Paris through comparison with the aethalometer model as described in Sect. 3.3. These particles exhibit a dominant small mass mode at $280 \mathrm{~nm}$ and a less pronounced, broader mass mode at $750 \mathrm{~nm}$ (Fig. 3).

\subsubsection{EC attributed to traffic (ECtraffic)}

ECtraffic mass spectra are characterised by signals for sodium $[\mathrm{Na}]^{+}$and calcium $[\mathrm{Ca}]^{+}$possibly arising from lubricating oil in the positive ion mass spectra (Shields et al., 2007), and elemental carbon fragment ions $\left[\mathrm{C}_{n}\right]^{-}$in the negative ion mass spectra. Similar single particle mass spectra have been observed in ATOFMS dynamometer studies of light and heavy duty vehicle emissions (Spencer et al., 2006; Shields et al., 2007; Toner et al., 2006) and in several urban field studies (Shields et al., 2008; Moffet et al., 2008a; Healy et al., 2010), although combustion sources other than traffic cannot be completely ruled out. 2 separate classes were originally observed, differing only in the relative intensities for sodium and calcium. However, these 2 classes exhibited identical size distributions and temporal trends and were thus merged into a single class. The average mass spectrum for this final class is shown in Fig. 1. ECtraffic particles peaked during the morning and evening rush hours, as expected for a local vehicular source (Fig. 2), and exhibit a single mass mode at $215 \mathrm{~nm}$, suggesting relatively fresh emission. It must be emphasised that the large scaling factors, assumption of sphericity in the conversion of $d_{\mathrm{va}}$ to $d_{\mathrm{ve}}$, and the assumption of a single particle density equal to the bulk particle density, are more likely to cause inaccuracy when scaling potentially fractal ECtraffic particles compared to the aged EC-containing particles discussed below (Moffet and Prather, 2009). It can be seen in Fig. 3 that 


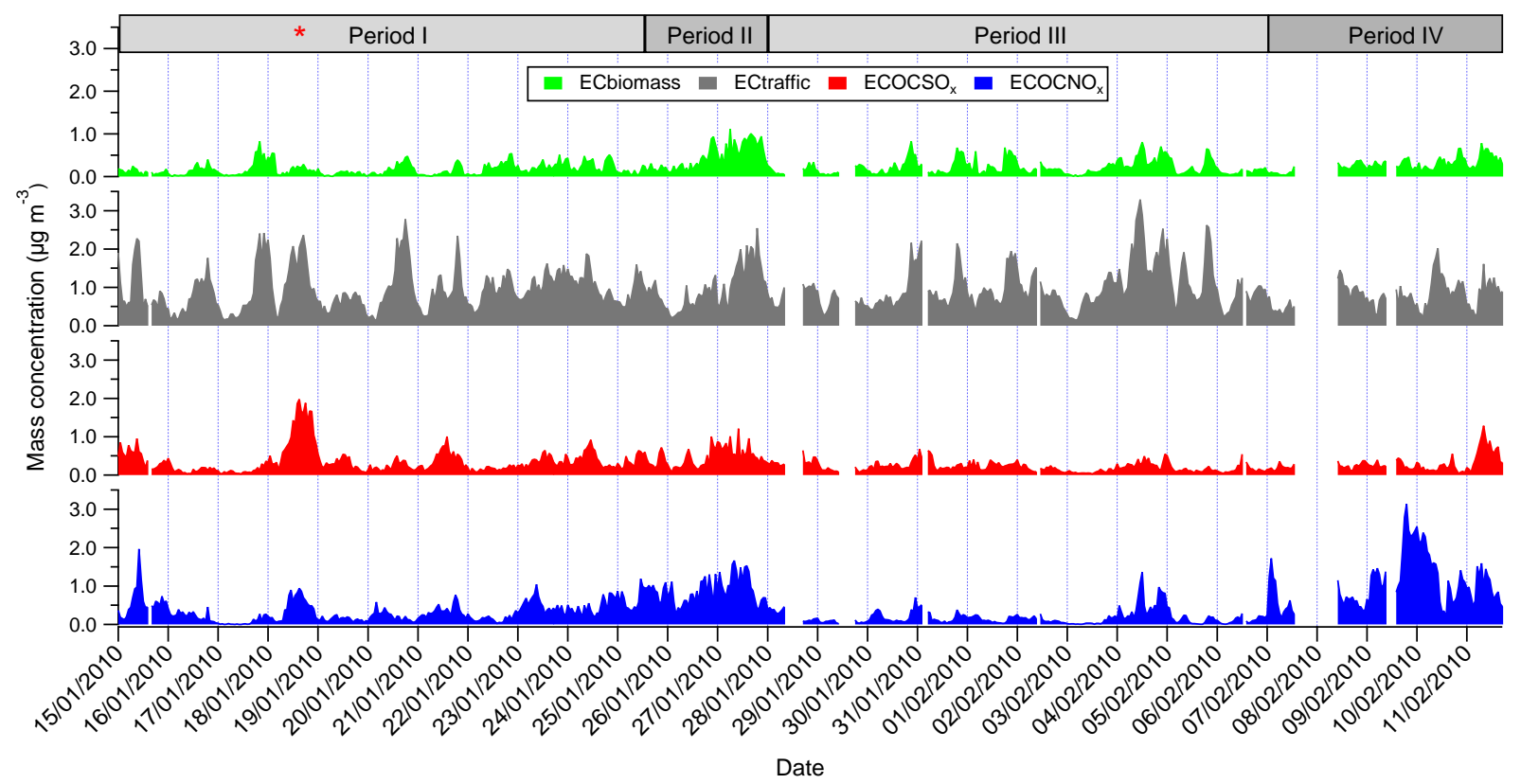

Fig. 4. Temporal trends of hourly scaled mass concentrations for the 4 ATOFMS EC classes. The measurement period is split into 4 parts as described in Sect. 3.2. The red asterisk denotes the fog event.

the mass size distribution continues below the lower sizing limit of the ATOFMS $(150 \mathrm{~nm})$, and thus a fraction of the mass remains unaccounted for. The "missing" mass fraction below $150 \mathrm{~nm}$ is expected to be comparatively smaller for the other EC classes. An extrapolation of a lognormal fit of the average particle mass size mode for the smaller EC particles $(150-400 \mathrm{~nm})$ to sizes below $150 \mathrm{~nm}$ is given in Fig. S3. The average contribution to total EC particle mass below this size range is estimated to be relatively low $(\sim 9 \%)$, and because no mass spectral information is available to confirm the mixing state of smaller particles, only the size range 150 $1067 \mathrm{~nm}$ is used here for source apportionment and reconstruction of EC particle mass. This undetected fraction could be minimised if an Ultrafine Aerosol Time-of-Flight Mass Spectrometer (UF-ATOFMS) is employed with a lower sizing limit of approximately $50 \mathrm{~nm}$ (Su et al., 2003; Shields et al., 2008). Coupling a hygroscopic growth tube to the UFATOFMS, to swell even smaller EC particles to a detectable size, would also help (Zauscher et al., 2011).

\subsubsection{EC internally mixed with $\mathrm{OC}$ and ammonium sulfate $\left(\mathrm{ECOCSO}_{\mathbf{x}}\right)$}

$\mathrm{ECOCSO}_{\mathrm{x}}$ particles exhibit signals for ammonium $\left[\mathrm{NH}_{3}\right]^{+}$, $\left[\mathrm{NH}_{4}\right]^{+}$, organic carbon $\left[\mathrm{C}_{2} \mathrm{H}_{3} \mathrm{O}\right]^{+}$, and a small signal for sodium $[\mathrm{Na}]^{+}$in the positive ion mass spectra, along with elemental carbon fragment ions $\left[\mathrm{C}_{\mathrm{n}}\right]^{-}$and a relatively high signal for sulfate in the negative ion spectra $\left[\mathrm{HSO}_{4}\right]^{-}$ $(\mathrm{m} / \mathrm{z}=-97)$ (Fig. 1). The $m / z=-97$ ion can also be assigned to phosphate $\left[\mathrm{H}_{2} \mathrm{OPO}_{3}\right]^{-}$for single particle mass spectra collected in fresh heavy duty vehicle exhaust (Toner et al., 2006), although a corresponding fragment ion at $\mathrm{m} / \mathrm{z}=-79$ $\left[\mathrm{PO}_{3}\right]^{-}$is not observed here, suggesting that sulfate is the correct assignment in this case. Examination of the HR-ToFAMS data for inorganic ions reveals that periods of elevated $\mathrm{ECOCSO}_{\mathrm{x}}$ mass concentrations are also characterised by elevated ammonium and sulfate mass concentrations (Fig. S4). $\mathrm{ECOCSO}_{\mathrm{x}}$ particles do not exhibit a strong diurnal trend, although an apparent enhancement from 09:00 to 13:00 (local time) suggests that these particles may arise at least partly through processing of locally emitted ECtraffic particles. Diurnal photochemical processing of fresh fractal soot particles emitted in the early morning hours to form spherical aged soot particles in the afternoon has been directly observed by ATOFMS in Mexico City (Moffet et al., 2008a; Moffet and Prather, 2009). Those particles contained internally mixed OC, ammonium, sulfate and nitrate. Sulfate was observed even in fresh particles, suggesting rapid condensation in the combustion plume. A dominant mass mode at $215 \mathrm{~nm}$ for $\mathrm{ECOCSO}_{\mathrm{x}}$ particles, similar to that of ECtraffic, also supports a fossil fuel combustion source, but suggests that significant growth of local EC particles to larger sizes through further accumulation of sulfate does not consistently occur throughout the measurement period. The highest concentrations of these particles were observed during a low wind speed fog event, as described in detail in Sect. 3.2, indicating that $\mathrm{ECOCSO}_{\mathrm{x}}$ particles are at least partly formed through heterogeneous processing of locally emitted EC particles. Identifying a specific source for these particles is difficult and is discussed below in Sect. 3.2. 

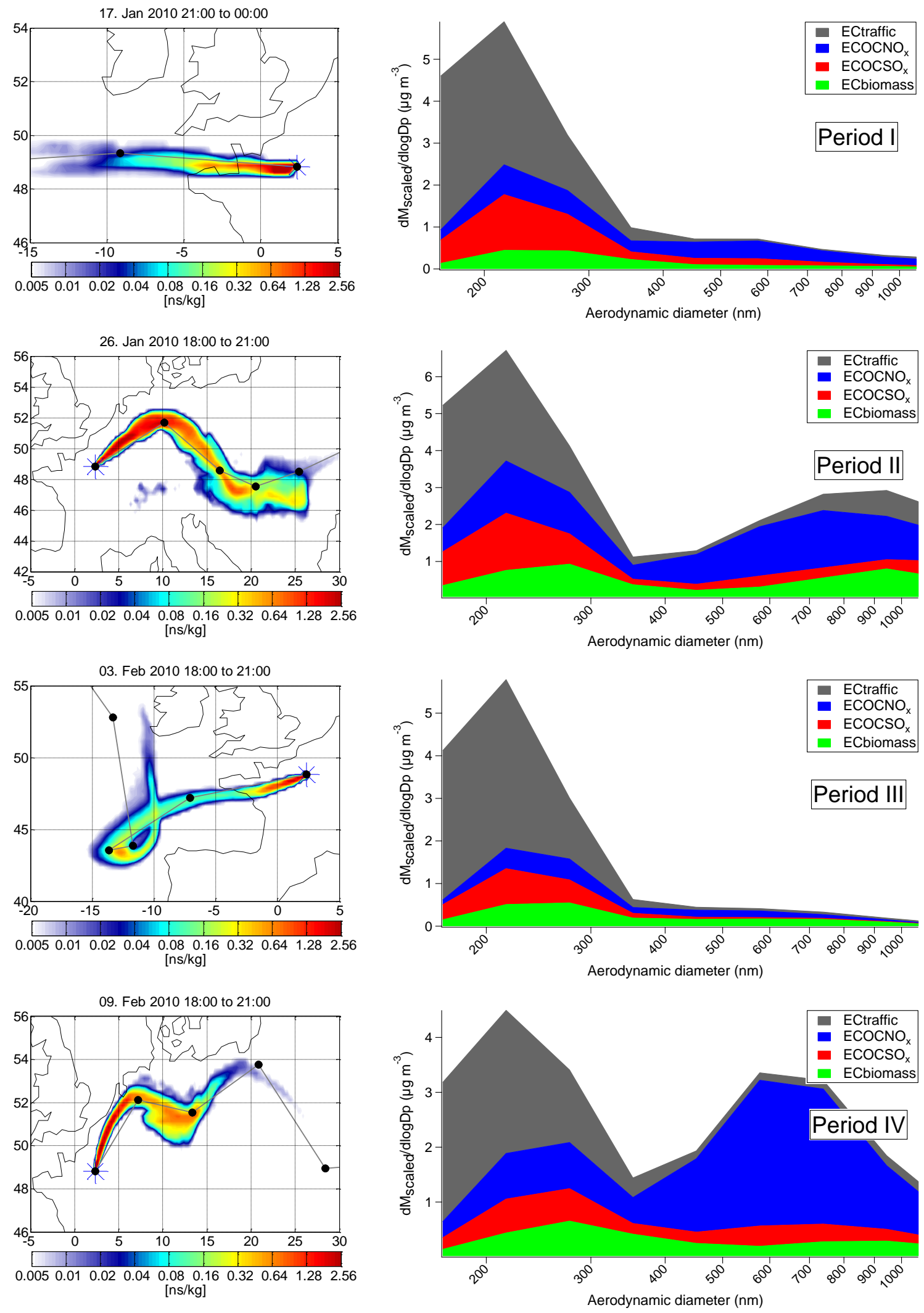

Fig. 5. Characteristic potential emission sensitivities (left) and average scaled mass size distributions for the 4 ATOFMS EC classes (right, stacked) for the 4 periods defined in Sect. 3.2. The dots in the potential emission sensitivity plots correspond to the air mass age in days, and are positioned on the centroid of the retroplume position at that time. FLEXPART details are provided in Sect. 2.4. 


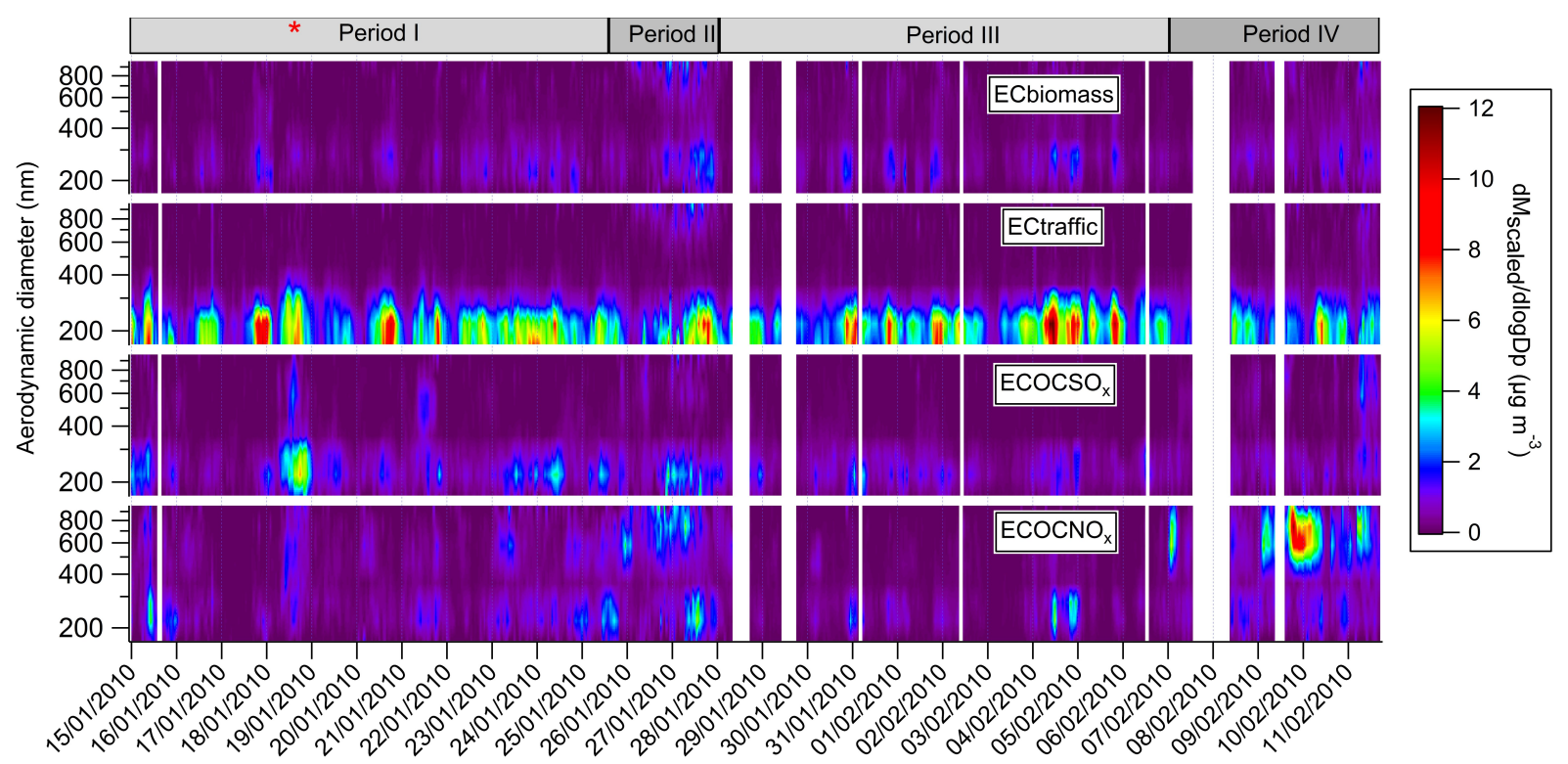

Date

Fig. 6. Hourly scaled mass size distributions for the 4 ATOFMS EC classes.

\subsubsection{EC internally mixed with $\mathrm{OC}$ and ammonium nitrate $\left(\mathrm{ECOCNO}_{\mathbf{x}}\right)$}

These particles are characterised by very similar positive ion mass spectra to $\mathrm{ECOCSO}_{\mathrm{x}}$, but exhibit relatively lower signals for sulfate and an additional intense signal for nitrate in the negative ion spectra $\left[\mathrm{NO}_{2}\right]^{-},\left[\mathrm{NO}_{3}\right]^{-}$(Fig. 1). $\mathrm{ECOCNO}_{\mathrm{x}}$ particles do not have any apparent diurnal trend, indicating a regional/long-range transport origin, and are on average the largest EC-containing particles observed, with a dominant mass mode at $580 \mathrm{~nm}$. This is in direct contrast to the other $3 \mathrm{EC}$ classes, each characterised by a dominant smaller mass mode $<300 \mathrm{~nm}$. ECOC particles with various intensities for nitrate and sulfate are often detected in urban ATOFMS field studies (Dall'Osto and Harrison, 2006; Moffet et al., 2008a; Ault et al., 2009). BC particles with coatings containing nitrate have also been observed in Tokyo, but this was a minor contributor to coating composition relative to sulfate and OC (Shiraiwa et al., 2007). Ammonium nitrate will condense on particle surfaces during atmospheric transport if sulfate is fully neutralised and excess ammonia is available (Riemer et al., 2004). The HR-ToFAMS data demonstrates that periods of elevated $\mathrm{ECOCNO}_{\mathrm{x}}$ mass concentrations are also characterised by elevated ammonium and nitrate mass concentrations (Fig. S4). It appears that uptake of sulfate on EC surfaces occurs rapidly at a local level in Paris, while ammonium nitrate condensation occurs continuously over longer timescales during transport. This is borne out by the much larger size of $\mathrm{ECOCNO}_{\mathrm{x}}$ particles. Evidence for uptake of nitrate with increasing EC particle age, observed during a low-wind speed event, is also given in Sect. 3.2. The absence of a strong signal for potassium in the ECtraffic, $\mathrm{ECOCSO}_{\mathrm{x}}$ and $\mathrm{ECOCNO}_{\mathrm{x}}$ mass spectra suggests that biomass burning does not contribute to these classes. Confirmation of the assignment of these three classes to fossil fuel combustion by comparison with the seven-wavelength $(7-\lambda)$ aethalometer modelled BC data is provided in Sect. 3.3.

\subsection{Identification of aerosol transport events}

A combination of temporal trends and mass size distributions for the ATOFMS EC classes (Figs. 4, 5 and 6) and LPDM FLEXPART retroplumes (Fig. 5) were employed to split the measurement campaign into 4 periods. The air masses observed were broadly similar to those influencing air quality in Paris in Spring 2007 (Sciare et al., 2010). As shown in Fig. 5, although the EC mass size distribution for Paris is bimodal, the relative importance of the second, larger mode is completely dependent upon air mass origin.

Period I (15 January 2010, 00:00 LT to 25 January 2010, 12:00 LT) was influenced by marine air masses originating in the Atlantic Ocean with little influence from sources outside Paris. During this period, EC particles below $400 \mathrm{~nm}$ diameter dominate the mass size distribution and are attributed to local domestic wood burning and traffic emissions (Figs. 5 and 6). A low wind speed fog event was observed on 18 January 2010, during which growth of EC particles to larger sizes was observed, and is described in more detail below.

Period II (25 January 2010, 12:00 LT to 28 January 2010, 00:00 LT) was characterised by a continental air mass originating in Eastern Europe. The retroplumes suggest that this 
air mass was sensitive to ground level emissions for up to 4 days before arriving in Paris. This is supported by the second, larger EC mass size mode peaking at $950 \mathrm{~nm}$ (Fig. 5). These particles are significantly aged, and are the largest EC particles observed for the entire measurement period. A significant fraction of this larger mode is comprised of transported ECtraffic and ECbiomass particles (Figs. 5 and 6) that do not exhibit sufficiently different mass spectra to be separated from their smaller local analogues during the clustering procedure.

Period III (28 January 2010, 00:00 LT to 7 February 2010, 00:00 LT) was similar to period I, but dominated by polar as well as marine air masses with very little sensitivity to ground level aerosol emissions. This was the cleanest period with respect to $\mathrm{ECOCSO}_{\mathrm{x}}$ and $\mathrm{ECOCNO}_{\mathrm{x}}$ particle mass concentrations (Fig. 4) and persisted for 10 days. It is also clear that fresh ECbiomass and ECtraffic particles $<400 \mathrm{~nm}$ are unaffected by air mass origin, confirming their assignment to local traffic and domestic wood combustion sources (Figs. 4, 5 and 6).

Period IV (7 February 2010, 00:00 LT to 11 February 2010, 17:00 LT) was influenced by a continental air mass sensitive to emissions in North Eastern Europe and the Benelux countries (Fig. 5). The second, larger EC mass size mode is smaller than that observed for period II $(580 \mathrm{~nm})$, indicating that less aging has occurred. This assumption is borne out by the corresponding retroplumes, suggesting significant sensitivity to ground level aerosol emissions of up to 3 days (Fig. 5); a value lower than the sensitivity duration observed for period II (4 days). The EC mass size distribution observed for period IV is strongly dominated by large $\mathrm{ECOCNO}_{x}$ particles. Significant enhancement of particle phase light-scattering inorganic ammonium salt concentrations were also observed when similar air masses influenced air quality in Paris in 2007 (Sciare et al., 2010). In fact, the majority of particle phase ammonium sulfate and ammonium nitrate in Paris was assigned to continental transport in that case.

A distinct fog event was identified during Period I. As shown in Fig. 4, denoted by a red asterisk, a significant increase in mass concentration is observed for $\mathrm{ECOCSO}_{\mathrm{x}}$ on 18 January 2010. A corresponding increase in sulfate mass concentration is also observed in the HR-ToF-AMS data (Fig. S4). There is no significant shift in air mass origin from 17 January 2010-18 January 2010 (Figs. 5 and S5). Instead, this day was characterised by the lowest average wind speed of the campaign, coupled with high relative humidity (Fig. S6). The Eulerian regional chemistry transport model CHIMERE, described in detail elsewhere (Sciare et al., 2010), estimated a relatively low contribution (15\%) of local emissions from within the Greater Paris (Ile de France, IDF) region to levels of particulate phase sulfate in Spring 2007. However, under low wind speed conditions, local contributions were predicted to dominate. The low wind speed suggests that $\mathrm{ECOCSO}_{\mathrm{x}}$ particles arise at least partly from local processing of EC. In fact, the highest mass concentrations of $\mathrm{ECOCSO}_{\mathrm{x}}$ particles for the entire measurement period are observed during this event. Emissions from coastal regions to the West of Paris cannot be completely ruled out as a potential source of $\mathrm{ECOCSO}_{\mathrm{x}}$ particles, however. Shipping and petrochemical industry sources are present along the English Channel, and air masses arriving at the site on 18 January 2010 are susceptible to ground level emissions along the Northwest coast of France (Fig. S5). Although fresh ship exhaust particle mass spectra detected in Cork Harbour using ATOFMS were found to consistently contain vanadium, iron and nickel, these metals are not observed in $\mathrm{ECOCSO}_{\mathrm{x}}$ particles (Healy et al., 2009, 2010). A previous ATOFMS study performed in the Port of Los Angeles demonstrated that not all ship plume combustion particles contain vanadium signatures however, because not all ships are using residual fuel oil (bunker fuel) (Ault et al., 2010). The soot particles assigned to ship plumes from vessels using cleaner distillate fuel in Los Angeles do exhibit similar positive ion mass spectra to the $\mathrm{ECOCSO}_{\mathrm{x}}$ particles observed in this work, however there was little or no sulfate signal detected in the Los Angeles case. The specific origin of $\mathrm{ECOCSO}_{\mathrm{x}}$ particles remains difficult to confirm, however the processing of these particles can be demonstrated to occur at a local level. The presence of thick fog is evident in a photograph taken on 18 January 2010 (Fig. S7). As shown in Fig. 6, ECOCSO ${ }_{x}$ and ECtraffic particles $<400 \mathrm{~nm}$ dominate this period. However, a small mass contribution from larger $\mathrm{ECOCSO}_{\mathrm{x}}$ and $\mathrm{ECOCNO}_{\mathrm{x}}$ particles $(>400 \mathrm{~nm})$ is also observed. It is likely that the larger particles arise from growth of local EC through heterogeneous processing. Hydroxymethanesulfonate $(\mathrm{m} / \mathrm{z}=-111)$ has previously been used as a tracer for aqueous processing of ambient particles in ATOFMS field studies (Whiteaker and Prather, 2003; Dall'Osto et al., 2009a). The formation of this species through aqueous complexation of sulfite and formaldehyde is highly dependent upon relative humidity (Whiteaker and Prather, 2003). Difference mass spectra for $\mathrm{ECOCSO}_{\mathrm{x}}$ and $\mathrm{ECOCNO}_{\mathrm{x}}$ particles smaller and larger than $400 \mathrm{~nm}$ detected on 18 January 2010 are given in Fig. S8. For $\mathrm{ECOCSO}_{\mathrm{x}}$, the larger particles are characterised by enhanced signals for ammonium $\left[\mathrm{NH}_{3}\right]^{+},\left[\mathrm{NH}_{4}\right]^{+}$, OC $\left[\mathrm{C}_{2} \mathrm{H}_{3} \mathrm{O}\right]^{+}$, sulfite $\left[\mathrm{SO}_{3}\right]^{-}$, [ $\left.\mathrm{HSO}_{3}\right]^{-}$and hydroxymethanesulfonate $\left[\mathrm{HOCH}_{2} \mathrm{SO}_{3}\right]^{-}$. The largest enhancement, however, is observed for nitrate $\left[\mathrm{NO}_{3}\right]^{-}$The difference mass spectra for $\mathrm{ECOCNO}_{\mathrm{x}}$ particles show that larger particles are also characterised by enhanced signals for ammonium, OC and sulfite. Again, however, the largest enhancement is observed for nitrate. An increase in ammonium and nitrate mass concentration is also observed in the HR-ToFAMS data (Fig. S4). Thus, it appears that while both particle types undergo at least some fog processing, the increase in size results predominantly from uptake of ammonium nitrate and OC. A similar dependence of particulate phase ammonium nitrate enhancement upon high relative humidity has been previously observed in Paris (Sciare et al., 


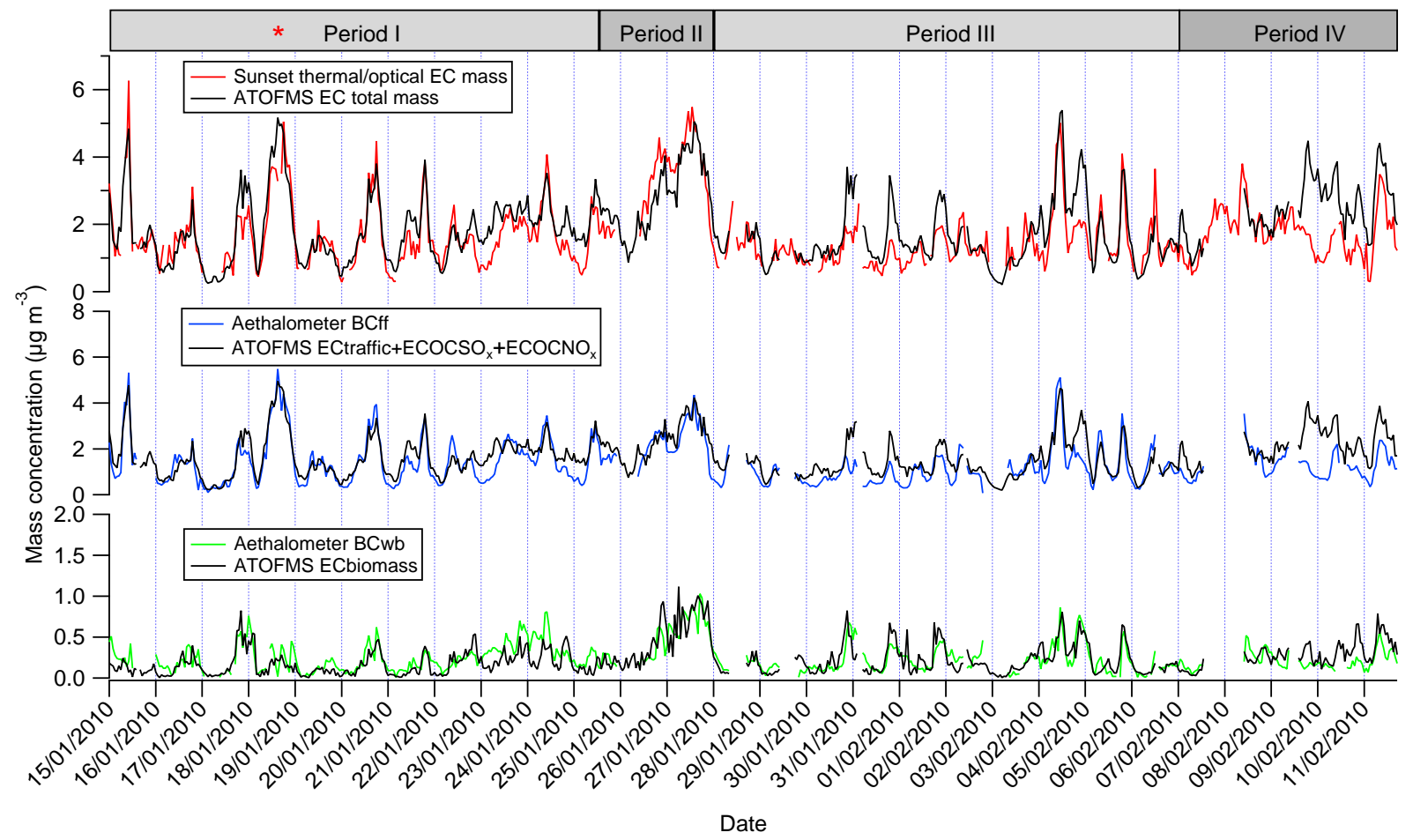

Fig. 7. Top: comparison of total scaled hourly ATOFMS EC particle mass concentration and hourly average Sunset thermal/optical EC mass concentration. Middle: scaled ATOFMS mass concentration for the sum of ECtraffic, $\mathrm{ECOCSO}_{\mathrm{x}}$ and $\mathrm{ECOCNO}_{\mathrm{x}}$ compared with hourly average modelled aethalometer $\mathrm{BC}_{\mathrm{ff}}$ mass concentration. Bottom: scaled ATOFMS mass concentration for ECbiomass compared with hourly average modelled aethalometer $\mathrm{BC}_{\mathrm{bb}}$ mass concentration.

2010). Humidity-dependent processing of EC particles, involving uptake of ammonium nitrate, liquid water and $\mathrm{OC}$ has also been directly observed by ATOFMS in Riverside, CA in the autumn (Moffet et al., 2008b). The density of the majority of particles detected during that study was found to be $\sim 1.5 \mathrm{~g} \mathrm{~cm}^{-3}$, the single value used for the scaling procedures here.

\subsection{Intercomparison of EC and BC measurements}

A comparison of the ATOFMS EC particle mass, Sunset EC, MAAP BC and aethalometer BC mass concentrations, and corresponding correlation plots are given in Figs. S9-14. The average mass concentrations reported by the 4 instruments for the entire measurement period are: ATOFMS EC particle mass $\left(2.02 \mu \mathrm{g} \mathrm{m}^{-3}\right)$, MAAP BC $\left(1.95 \mu \mathrm{g} \mathrm{m}^{-3}\right)$, Sunset EC $\left(1.70 \mu \mathrm{g} \mathrm{m}^{-3}\right)$, aethalometer BC $\left(1.66 \mu \mathrm{g} \mathrm{m}^{-3}\right)$. These values are broadly in line with average $\mathrm{BC}$ mass concentrations observed at other European urban background sites in Barcelona, Lugano and London (1.7, 1.8 and $1.9 \mu \mathrm{g} \mathrm{m}^{-3}$ respectively) (Reche et al., 2011). Unsurprisingly, the ATOFMS reports the highest mass values due to contributions from non-EC secondary species in the volume calculations, although this value remains within $20 \%$ of the average BC and Sunset EC mass concentrations. Agreement is also very good between the MAAP, aethalometer and Sunset instruments $\left(r^{2}=0.86-0.94\right.$, Figs. S9-11). Differences between the aethalometer and MAAP BC datasets are expected to be mostly due to differences in the corrections used to account for scattering effects (Petzold and Schönlinner, 2004). The MAAP absorption data is internally corrected for particle and filter scattering, and thus an established MAE $_{637 \mathrm{~nm}}$ value of $6.60 \mathrm{~m}^{2} \mathrm{~g}^{-1}$ is used (Müller et al., 2011). The aethalometer absorption data is not internally corrected for scattering and thus a MAE $950 \mathrm{~nm}$ value was derived from comparison with the thermal/optical EC data $\left(5.08 \mathrm{~m}^{2} \mathrm{~g}^{-1}\right)$. Differences between MAAP BC and thermal/optical EC mass concentrations have been previously reported in winter intercomparisons influenced by biomass burning, and may be partly due to the presence of light-absorbing brown carbon (Reisinger et al., 2008). Another possibility is that the thermal (NIOSH) program implemented in the OCEC instrument may be inappropriate for the analysis of woodburning aerosols, leading to an underestimation of EC from this source (Sciare et al., 2003, 2008).

A comparison of the hourly scaled ATOFMS EC mass concentrations and the hourly averaged Sunset thermal/optical EC data is given in Figs. 7 and S13. The agreement observed is reasonably good $\left(r^{2}=0.61\right.$, slope $\left.=0.79\right)$ considering the possible sources of error associated with the ATOFMS scaling procedures. Non-spherical fractal particles 
exhibit different shape factors and particle densities to spherical particles, and perpendicular drag forces impact upon the transmission efficiency of the former through the instrument (Moffet and Prather, 2009). The largest, most sustained discrepancy is the overestimation of the ATOFMS EC particle mass relative to the Sunset EC during period IV (Fig. 7), which is also characterised by a much lower $r^{2}$ value of 0.30 . A significant fraction of the ATOFMS EC-containing particle volume for this period is expected to be ammonium nitrate and OC (Fig. S8), thus the ATOFMS EC particle mass is significantly higher than the Sunset EC mass. If period IV is removed, the agreement between the ATOFMS EC particle mass and the Sunset EC mass noticeably improves $\left(r^{2}=0.71\right.$, slope $=0.88$ ). Good agreement was also observed between ATOFMS EC particle mass and aethalometer BC and MAAP $\mathrm{BC}$ mass for the entire measurement period $\left(r^{2}=0.65\right.$ and 0.68 respectively). The same discrepancy observed between the ATOFMS EC particle mass and the Sunset EC is also apparent in the MAAP and aethalometer BC datasets during Period IV (Figs. S12 and S14).

The relative abundance of internally mixed EC and OC in soot particles has been previously determined from relative ion intensities in single particle mass spectra, collected both in laboratory studies and in the field, and validated with OCEC thermal/optical measurements (Ferge et al., 2006; Spencer and Prather, 2006). Specific ion relative intensities in single particle mass spectra have also been used to estimate their respective particle volume fractions and thus mass concentrations (Jeong et al., 2011). That approach resulted in effective mass reconstruction for inorganic ions but proved less satisfactory for EC and OC, probably due to matrix effects during ionization of particle phase species (Reinard and Johnston, 2008). The EC volume fraction of soot particles detected by ATOFMS in Mexico City and Riverside, California has previously been estimated using Mie theory (Moffet and Prather, 2005, 2009). The intensity of scattered light detected by the photomultiplier tubes in the sizing region of the instrument was used to estimate the EC "core" diameter. Scattered light was not recorded in this study, but a similar core volume estimation approach is expected to improve agreement between the ATOFMS and other EC and BC instruments if employed in future studies. In the absence of EC volume fraction estimates, the EC particle mass reported here includes contributions from internally mixed secondary components. Despite this, the relatively high correlations observed indicate that single particle mass spectrometers can be used to estimate EC mass concentrations at high temporal resolution in urban environments dominated by fresh EC emissions, even without volume fraction estimates.

\subsection{Source apportionment of EC and BC}

The aethalometer data provides an opportunity for validating the source assignment of the ATOFMS particle types. Modelled aethalometer mass concentrations for the fossil fuel fraction $\left(\mathrm{BC}_{\mathrm{ff}}\right)$ and biomass burning fraction $\left(\mathrm{BC}_{\mathrm{bb}}\right)$ of $\mathrm{BC}$ are compared with the sum of ATOFMS EC classes expected to arise from fossil fuel combustion (ECtraffic $+\mathrm{ECOCSO}_{\mathrm{x}}+\mathrm{ECOCNO}_{\mathrm{x}}$ ) and the ATOFMS ECbiomass class in Fig. 7. Agreement is reasonable $\left(r^{2}=0.60\right.$ and 0.48 for fossil fuel and biomass burning respectively), although the aethalometer values are consistently lower. This is expected as the aethalometer also reports the lowest $\mathrm{BC}$ concentrations overall, however the more pronounced overestimation of the ATOFMS for fossil fuel EC, most dramatic during period IV, is due to internally mixed OC and inorganic ions. Again, if period IV is removed, the correlation improves $\left(r^{2}=0.72\right.$ and 0.53 for fossil fuel and biomass burning respectively). The average EC particle mass assigned to fossil fuel and biomass burning for Paris using the ATOFMS data is $88 \%$ and $12 \%$ respectively, while the modelled BC fraction from the aethalometer data is $85 \%$ and $15 \%$ respectively. Internally mixed secondary species contribute to the higher fossil fuel fraction observed for ATOFMS EC particle mass, because the larger transported particles arise predominantly from fossil fuel combustion (Fig. 5). The aethalometer model has been previously compared with carbon isotope $\left({ }^{14} \mathrm{C}\right)$ measurements to identify suitable Absorption Exponents for wood-burning and traffic aerosol, and subsequent intercomparisons of aethalometer-modelled woodburning organic aerosol with the chemical mass balance and AMS factor analysis approaches resulted in good agreement $\left(r^{2}=0.84\right.$ and 0.85, respectively) (Sandradewi et al., 2008a; Favez et al., 2010; Sciare et al., 2011). The agreement observed with the ATOFMS classes is encouraging, suggesting that effective separation of biomass burning and fossil fuel contributions to EC particle mass can be achieved using single particle mass spectrometry. The value reported here for the fraction of $\mathrm{BC}$ apportioned to biomass burning $(15 \%)$ is lower than those obtained in winter months for an urban site in Zürich, and a rural Alpine village in Switzerland (25\% and $51 \%$ respectively) using carbon isotope and aethalometer model approaches (Szidat et al., 2006; Herich et al., 2010; Sandradewi et al., 2008a). The value of $15 \%$ is close to those observed for urban sites in Göteborg, Sweden and Birmingham, UK in winter months as determined by carbon isotope analysis ( $12 \%$ and $\sim 10 \%$ respectively) (Szidat et al., 2009; Heal et al., 2011). The average mass concentration of biomass burning BC in this work $\left(0.25 \mu \mathrm{g} \mathrm{m}^{-3}\right)$ is very close to the average mass concentration measured at a suburban site in Paris in the winter months $\left(0.22 \mu \mathrm{g} \mathrm{m}^{-3}\right)$ using the same aethalometer model (Sciare et al., 2011). Despite a relatively low contribution compared to traffic, biomass burning does represent a significant source of BC in Paris and should be accounted for when considering PM abatement strategies. Furthermore, the contribution of biomass burning to organic matter is much higher than that observed for BC (Sciare et al., 2011). Methodologies that can separate the relative contribution of fossil fuel BC and biomass burning BC plumes will also be relevant for climate studies, as the former 


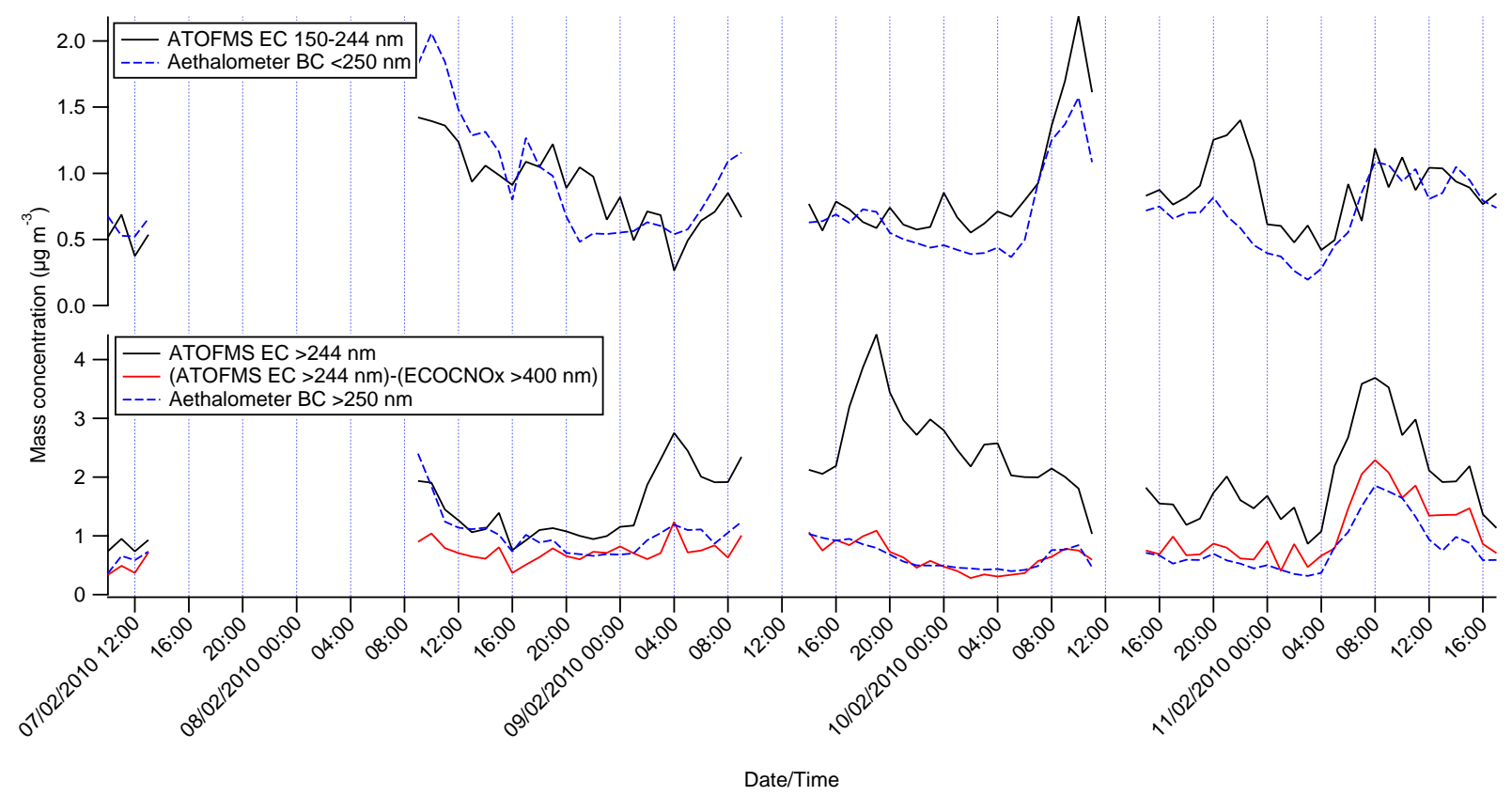

Fig. 8. Top: scaled ATOFMS EC particle mass concentration in the size range $150-244 \mathrm{~nm}$ and mass concentration of BC $<250 \mathrm{~nm}$ measured with the aethalometer. Bottom: scaled ATOFMS EC particle mass concentration $>244 \mathrm{~nm}$, scaled ATOFMS EC particle mass concentration $>244 \mathrm{~nm}$ minus ATOFMS ECOCNO $\mathrm{x}>400 \mathrm{~nm}$, and aethalometer $\mathrm{BC}>250 \mathrm{~nm}$ mass concentration estimated by comparing the two aethalometer datasets.

exhibits approximately $100 \%$ greater warming through absorption per unit mass than the latter (Ramana et al., 2010). Biomass burning particles have also been observed to induce oxidative stress and DNA damage in human lung epithelial cells (Danielsen et al., 2011).

Additional aethalometer data for BC mass $<250 \mathrm{~nm}\left(d_{\mathrm{a}}\right)$ for the period 05 February 2010-17 February 2010 demonstrate the different temporalities observed for BC particles of differing size in Paris. Subtraction of these values from the corresponding aethalometer $\mathrm{BC}$ mass $<2.5 \mu \mathrm{m}$ dataset provides values for $\mathrm{BC}>250 \mathrm{~nm}$. The $2 \mathrm{BC}$ size fractions are compared with each other and with ATOFMS EC particle mass in the size range $150-244 \mathrm{~nm}\left(d_{\mathrm{va}}\right)$ and ATOFMS EC particle mass $>244 \mathrm{~nm}\left(d_{\mathrm{va}}\right)$ in Fig. 8. Agreement between $\mathrm{BC}<250 \mathrm{~nm}$ and ATOFMS EC particle mass in the size range $150-244 \mathrm{~nm}$ is reasonable $\left(r^{2}=0.50\right)$. Poor agreement is observed between BC mass $>250 \mathrm{~nm}$ and ATOFMS EC particle mass $>244 \mathrm{~nm}\left(r^{2}=0.10\right)$. This is expected as the intercomparison was performed during period IV, which is characterised by an influx of large $\mathrm{ECOCNO}_{\mathrm{x}}$ particles with significant internally mixed secondary mass (Figs. 5 and 6). If the $\mathrm{ECOCNO}_{\mathrm{x}}$ particle mass $>400 \mathrm{~nm}$ is subtracted from the total ATOFMS EC particle mass $>244 \mathrm{~nm}$, much better agreement with the $\mathrm{BC}>250 \mathrm{~nm}$ is observed $\left(r^{2}=0.43\right)$, suggesting that a significant fraction of EC-containing particle mass detected by the ATOFMS during this period does arise from secondary $\mathrm{OC}$ and ammonium nitrate.
While the aethalometer measurements demonstrate different temporalities for BC of different sizes, $250 \mathrm{~nm}$ does not necessarily represent the best size cut-off for future studies attempting to estimate the relative importance of local and continental BC in Paris, at least during the winter months. Examination of the size-resolved mass concentrations of the summed ATOFMS EC classes enables the identification of a consistent minimum at $400 \mathrm{~nm}\left(d_{\mathrm{va}}\right)$ between the $2 \mathrm{EC}$ mass size modes (Figs. 5 and 9). The temporal trends for ATOFMS EC mass concentrations below and above $400 \mathrm{~nm}$ are shown in Fig. 10. The smaller mode follows a clear diurnal trend, irrespective of air mass origin, while the larger mode is associated with continental transport events (periods II and IV). The highest $\mathrm{PM}_{2.5}$ mass concentrations observed in Paris in Spring 2007 were also associated with continental transport events (Sciare et al., 2010). The data obtained in periods I and III show that the contribution of locally emitted EC particles to the larger mass size mode is in general very low. One exception is the fog event on 18 January 2010, when local EC particles grew to sizes larger than $400 \mathrm{~nm}$, although the mass contribution $>400 \mathrm{~nm}$ for this day is a factor of approximately 20 lower than the continental transport input for the rest of the measurement period. Growth of local EC particles to larger sizes through chemical processing has been observed to be more dramatic in Mexico City due to relatively high photochemical activity (Moffet and Prather, 2009). Using a cut-off of $400 \mathrm{~nm}$, local emissions and transport events are estimated to contribute on average 1.60 and $0.42 \mu \mathrm{g} \mathrm{m}^{-3}$, 


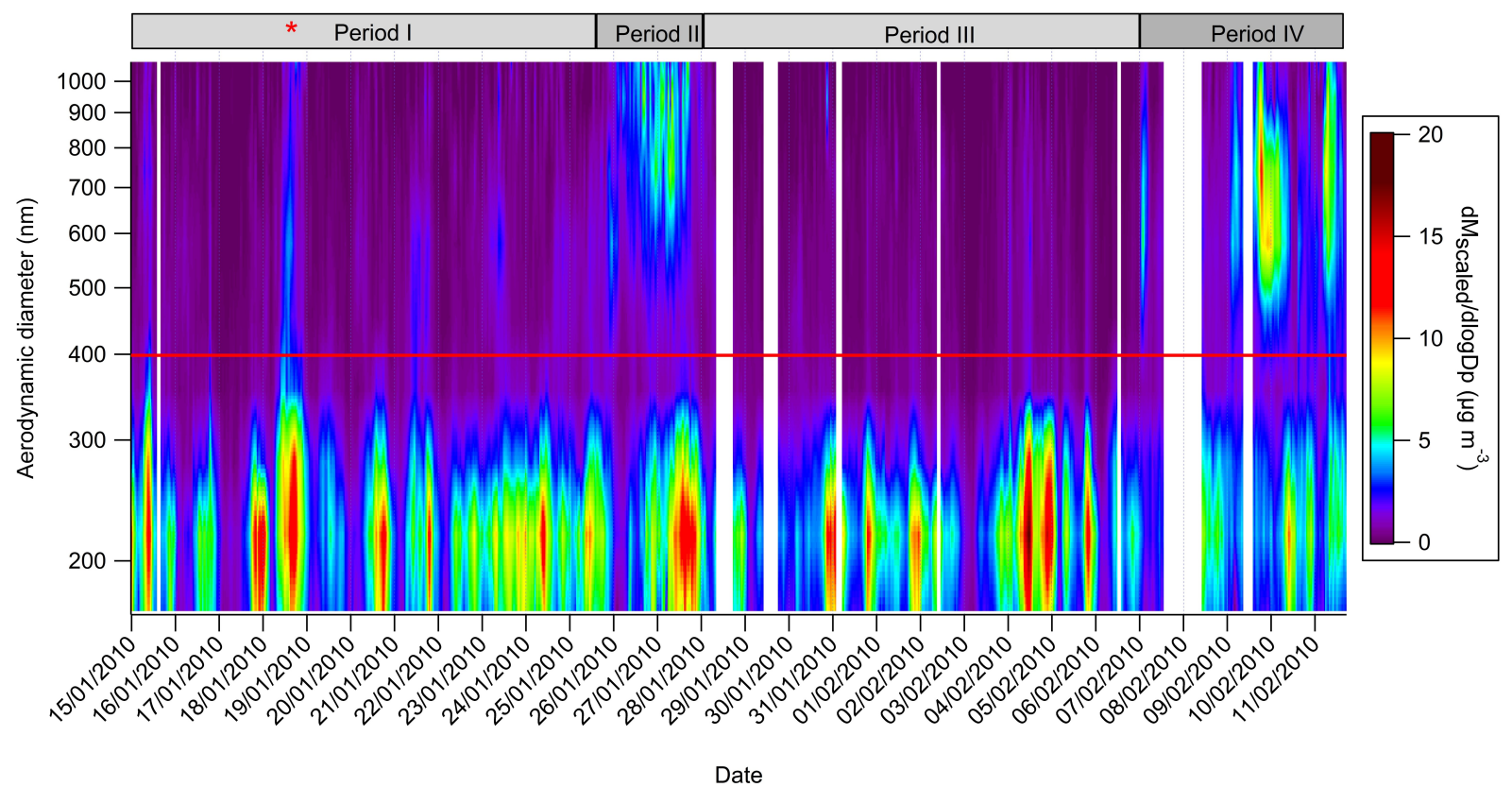

Fig. 9. Hourly total size-resolved ATOFMS scaled EC particle mass concentration. The minimum in the average bimodal EC particle mass size distribution at $400 \mathrm{~nm}$ is represented by the red line.

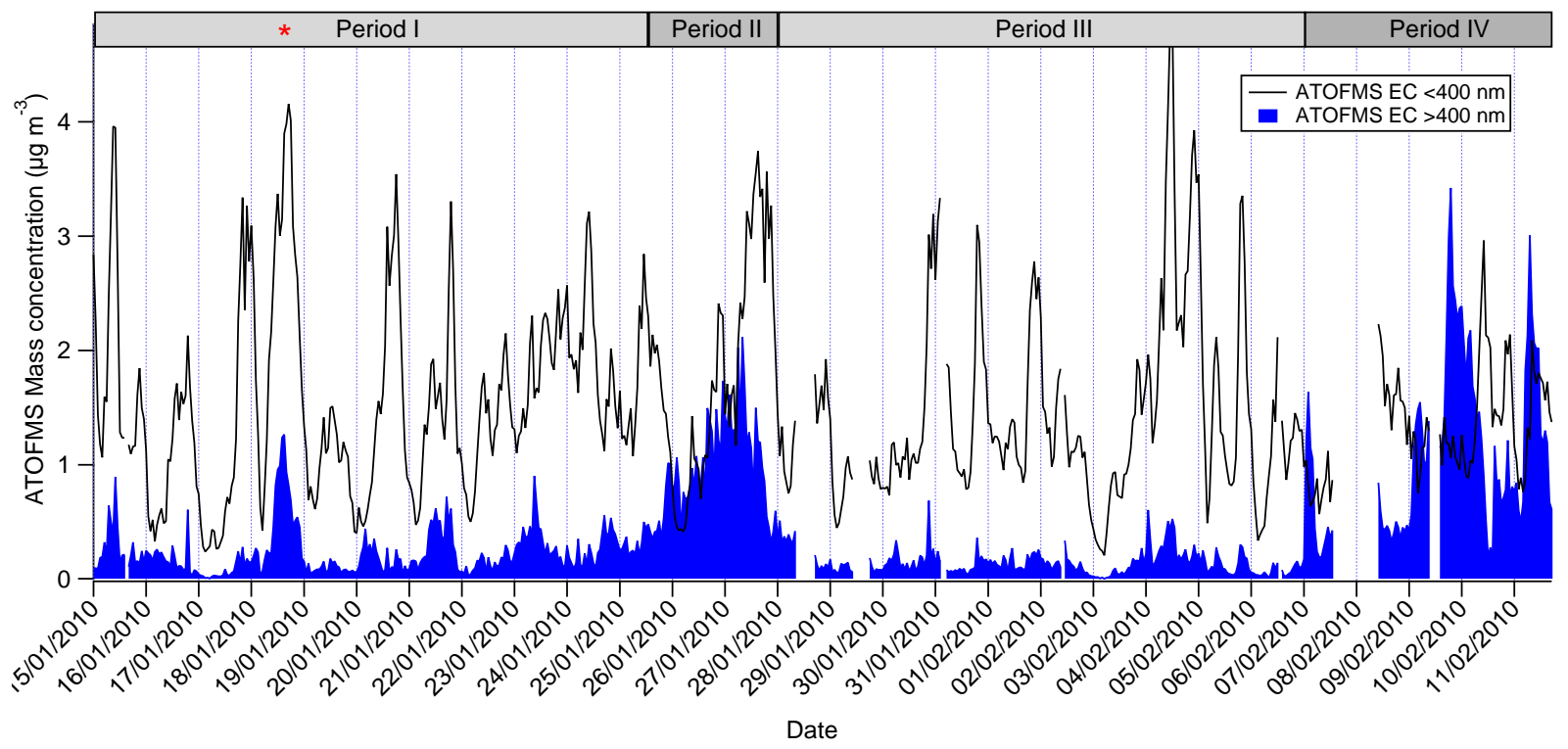

Fig. 10. Hourly scaled ATOFMS EC particle mass concentration for particles less than and greater than $400 \mathrm{~nm}$ in diameter.

respectively, to EC particle mass in Paris for the measurement period. However, the latter value must be considered as an upper limit for EC mass, as a significant fraction of the ATOFMS EC particle mass in that size range is comprised of secondary OC and ammonium nitrate. $90 \%$ and $10 \%$ of the local EC particle mass $(<400 \mathrm{~nm})$ is apportioned to fossil fuel combustion and biomass burning, respectively from the ATOFMS data, compared to $82 \%$ and $18 \%$, respectively for transported EC particle mass $(>400 \mathrm{~nm})$. A higher con- tribution from fossil fuel EC is expected for local emissions considering the significant vehicular traffic source in Paris.

A recent year-long source apportionment study based on the chemical composition of $\mathrm{PM}_{2.5}$ in Paris resulted in the identification of six major sources (Bressi et al., 2011). The sources identified were: Traffic, Wood burning, Oil combustion, Marine aerosol, an $\mathrm{NH}_{4} \mathrm{NO}_{3}$ rich source and an $\left(\mathrm{NH}_{4}\right)_{2} \mathrm{SO}_{4}$ rich source. The two inorganic ion rich factors were assigned to regional transport, consistent with the 
findings of Sciare et al. (2010). The Traffic factor was found to be of local origin. Wood burning was found to be local but also partially imported from the South. The Oil combustion contribution was deemed to be imported from regions outside the city to the North of Paris. The results are consistent with the findings of this work; that the two major local sources of carbonaceous $\mathrm{PM}_{2.5}$ in Paris are traffic and wood burning.

\section{Conclusions}

ATOFMS particle counts have been scaled to coincident TDMPS data in order to estimate mass concentrations of EC particles in Paris (France) during the MEGAPOLI winter measurement campaign. The results are in good agreement with the mass concentration of EC measured with a thermal/optical OCEC analyser and BC measured with a MAAP and $7-\lambda$ aethalometer. Four distinct EC single particle classes were identified and quantified using the ATOFMS data: ECtraffic, ECbiomass, $\mathrm{ECOCSO}_{\mathrm{x}}$ and $\mathrm{ECOCNO}_{\mathrm{x}}$, with fossil fuel and biomass burning contributions to EC particle mass estimated to be $88 \%$ and $12 \%$, respectively (compared to $85 \%$ and $15 \%$, respectively using aethalometer data). The results indicate that single particle mass spectrometry is suitable for source apportionment of EC, particularly in urban environments. On average, the EC particle mass size distribution in Paris is bimodal; a persistent smaller mode is dominated by locally emitted externally mixed EC particles, and a larger mode associated with continental transport events is dominated by aged, internally mixed $\mathrm{ECOCNO}_{\mathrm{x}}$ particles. The bimodal mass size distributions observed for EC particle mass exhibits a clear minimum at $400 \mathrm{~nm}$, allowing the relative local and continental transport mass input to be estimated at $79 \%$ and $21 \%$, respectively, although the latter must be considered as an upper limit for EC mass. The sizeresolved ATOFMS EC data reported here should also prove useful for modelling studies attempting to bridge the gap between estimated transported $\mathrm{BC}$ concentrations derived from emissions inventories and those measured in Paris. A simple size cut-off point of $400 \mathrm{~nm}$ could be used to estimate local and continental emissions of BC for future aethalometer measurements in Paris, and a similar approach may be suitable for other urban environments, although transported BC must be sufficiently aged to reside in a well separated mass size mode.

\section{Supplementary material related to this article is available online at: http://www.atmos-chem-phys.net/12/1681/2012/ acp-12-1681-2012-supplement.pdf.}

Acknowledgements. The authors would like to thank Valerie Gros and Matthias Beekmann for helping out with the campaign logistics, the LHVP for providing the sampling site and Météo-France for providing the meteorological data. The authors would also like to thank Nathan Stevenson for help with data processing. This research has been funded by the Higher Education Authority, Ireland under PRTLI cycle IV, the Irish Research Council for Engineering and Technology, and the European Union's Seventh Framework Programme FP/2007-2011 within the project MEGAPOLI (grant agreement no. 212520).

Edited by: M. Beekmann

\section{References}

Allen, J. O., Fergenson, D. P., Gard, E. E., Hughes, L. S., Morrical, B. D., Kleeman, M. J., Gross, D. S., Galli, M. E., Prather, K. A., and Cass, G. R.: Particle Detection Efficiencies of Aerosol Time of Flight Mass Spectrometers under Ambient Sampling Conditions, Environ. Sci. Technol., 34, 211-217, 2000.

Ault, A. P., Moore, M. J., Furutani, H., and Prather, K. A.: Impact of Emissions from the Los Angeles Port Region on San Diego Air Quality during Regional Transport Events, Environ. Sci. Technol., 43, 3500-3506, 2009.

Ault, A. P., Gaston, C. J., Wang, Y., Dominguez, G., Thiemens, M. H., and Prather, K. A.: Characterization of the Single Particle Mixing State of Individual Ship Plume Events Measured at the Port of Los Angeles, Environ. Sci. Technol., 44, 1954-1961, 2010.

Bae, M.-S., Schauer, J. J., DeMinter, J. T., Turner, J. R., Smith, D., and Cary, R. A.: Validation of a semi-continuous instrument for elemental carbon and organic carbon using a thermal-optical method, Atmos. Environ., 38, 2885-2893, 2004.

Bein, K. J., Zhao, Y., Pekney, N. J., Davidson, C. I., Johnston, M. V., and Wexler, A. S.: Identification of sources of atmospheric PM at the Pittsburgh Supersite-Part II: Quantitative comparisons of single particle, particle number, and particle mass measurements, Atmos. Environ., 40, 424-444, 2006.

Bi, X., Zhang, G., Li, L., Wang, X., Li, M., Sheng, G., Fu, J., and Zhou, Z.: Mixing state of biomass burning particles by single particle aerosol mass spectrometer in the urban area of PRD, China, Atmos. Environ., 45, 3447-3453, 2011.

Birmili, W., Stratmann, F., and Wiedensohler, A.: Design of a DMA-based size spectrometer for a large particle size range and stable operation, J. Aerosol Sci., 30, 549-553, 1999.

Bressi, M., Sciare, J., Ghersi, V., Mihalopoulos, N., Moukhtar, S., Rosso, A., Bonnaire, N., Nicolas, J., Petit, J. E., Feron, A., Artufel, M., and Cachier, H.: A comprehensive study of fine aerosols (PM2.5) in the region of Paris (France): chemical characterization, major sources, and geographical origins, European Aerosol Conference (EAC), Manchester, UK, 2011,

Clarke, A., McNaughton, C., Kapustin, V., Shinozuka, Y., Howell, S., Dibb, J., Zhou, J., Anderson, B., Brekhovskikh, V., Turner, H., and Pinkerton, M.: Biomass burning and pollution aerosol over North America: Organic components and their influence on spectral optical properties and humidification response, J. Geophys. Res., 112, D12S18, doi:10.1029/2006JD007777, 2007.

Collaud Coen, M., Weingartner, E., Apituley, A., Ceburnis, D., Fierz-Schmidhauser, R., Flentje, H., Henzing, J. S., Jennings, S. G., Moerman, M., Petzold, A., Schmid, O., and Baltensperger, U.: Minimizing light absorption measurement artifacts of the Aethalometer: evaluation of five correction algorithms, Atmos. Meas. Tech., 3, 457-474, doi:10.5194/amt-3-457-2010, 2010. 
Dall'Osto, M. and Harrison, R. M.: Chemical characterisation of single airborne particles in Athens (Greece) by ATOFMS, Atmos. Environ., 40, 7614-7631, 2006.

Dall'Osto, M., Harrison, R. M., Coe, H., and Williams, P.: Realtime secondary aerosol formation during a fog event in London, Atmos. Chem. Phys., 9, 2459-2469, doi:10.5194/acp-9-24592009, 2009a.

Dall'Osto, M., Harrison, R. M., Coe, H., Williams, P. I., and Allan, J. D.: Real time chemical characterization of local and regional nitrate aerosols, Atmos. Chem. Phys., 9, 3709-3720, doi:10.5194/acp-9-3709-2009, 2009b.

Danielsen, P. H., Møller, P., Jensen, K. A., Sharma, A. K., Wallin, H. k., Bossi, R., Autrup, H., Mølhave, L., Ravanat, J.-L., Briede, J. J., de Kok, T. M., and Loft, S.: Oxidative Stress, DNA Damage, and Inflammation Induced by Ambient Air and Wood Smoke Particulate Matter in Human A549 and THP-1 Cell Lines, Chem. Res. Toxicol., 24, 168-184, 2011.

DeCarlo, P. F., Slowik, J. G., Worsnop, D. R., Davidovits, P., and Jimenez, J. L.: Particle morphology and density characterization by combined mobility and aerodynamic diameter measurements. Part 1: Theory, Aerosol Sci. Technol., 38, 1185-1205, 2004.

DeCarlo, P. F., Kimmel, J. R., Trimborn, A., Northway, M. J., Jayne, J. T., Aiken, A. C., Gonin, M., Fuhrer, K., Horvath, T., Docherty, K. S., Worsnop, D. R., and Jimenez, J. L.: Field-Deployable, High-Resolution, Time-of-Flight Aerosol Mass Spectrometer, Anal. Chem., 78, 8281-8289, 2006.

Eatough, D. J., Grover, B. D., Woolwine, W. R., Eatough, N. L., Long, R., and Farber, R.: Source apportionment of $1 \mathrm{~h}$ semicontinuous data during the 2005 Study of Organic Aerosols in Riverside (SOAR) using positive matrix factorization, Atmos. Environ., 42, 2706-2719, 2008.

Favez, O., Cachier, H., Sciare, J., and Le Moullec, Y.: Characterization and contribution to $\mathrm{PM}_{2.5}$ of semi-volatile aerosols in Paris (France), Atmos. Environ., 41, 7969-7976, 2007.

Favez, O., Cachier, H., Sciare, J., Sarda-Estève, R., and Martinon, L.: Evidence for a significant contribution of wood burning aerosols to PM2.5 during the winter season in Paris, France, Atmos. Environ., 43, 3640-3644, 2009.

Favez, O., El Haddad, I., Piot, C., Boréave, A., Abidi, E., Marchand, N., Jaffrezo, J.-L., Besombes, J.-L., Personnaz, M.-B., Sciare, J., Wortham, H., George, C., and D'Anna, B.: Inter-comparison of source apportionment models for the estimation of wood burning aerosols during wintertime in an Alpine city (Grenoble, France), Atmos. Chem. Phys., 10, 5295-5314, doi:10.5194/acp-10-52952010, 2010.

Ferge, T., Karg, E., Schröppel, A., Coffee, K. R., Tobias, H. J., Frank, M., Gard, E. E., and Zimmermann, R.: Fast Determination of the Relative Elemental and Organic Carbon Content of Aerosol Samples by On-Line Single-Particle Aerosol Timeof-Flight Mass Spectrometry, Environ. Sci. Technol., 40, 33273335, 2006.

Fergenson, D. P., Song, X.-H., Ramadan, Z., Allen, J. O., Hughes, L. S., Cass, G. R., Hopke, P. K., and Prather, K. A.: Quantification of ATOFMS Data by Multivariate Methods, Anal. Chem., 73, 3535-3541, 2001.

Froyd, K. D., Murphy, S. M., Murphy, D. M., de Gouw, J. A., Eddingsaas, N. C., and Wennberg, P. O.: Contribution of isoprenederived organosulfates to free tropospheric aerosol mass, Proc. Natl. Acad. Sci. USA, 107, 21360-21365, 2010.
Gao, R. S., Schwarz, J. P., Kelly, K. K., Fahey, D. W., Watts, L. A., Thompson, T. L., Spackman, J. R., Slowik, J. G., Cross, E. S., Han, J.-H., Davidovits, P., Onasch, T. B., and Worsnop, D. R.: A Novel Method for Estimating Light-Scattering Properties of Soot Aerosols Using a Modified Single-Particle Soot Photometer, Aerosol Sci. Technol., 41, 125-135, 2007.

Gard, E., Mayer, J. E., Morrical, B. D., Dienes, T., Fergenson, D. P., and Prather, K. A.: Real-Time Analysis of Individual Atmospheric Aerosol Particles: Design and Performance of a Portable ATOFMS, Anal. Chem., 69, 4083-4091, 1997.

Gros, V., Sciare, J., and Yu, T.: Air-quality measurements in megacities: Focus on gaseous organic and particulate pollutants and comparison between two contrasted cities, Paris and Beijing, C. R. Geosci., 339, 764-774, 2007.

Gross, D. S., Galli, M. E., Kalberer, M., Prevot, A. S. H., Dommen, J., Alfarra, M. R., Duplissy, J., Gaeggeler, K., Gascho, A., Metzger, A., and Baltensperger, U.: Real-time measurement of oligomeric species in secondary organic aerosol with the aerosol time-of-flight mass spectrometer, Anal. Chem., 78, 2130-2137, 2006.

Gross, D. S., Atlas, R., Rzeszotarski, J., Turetsky, E., Christensen, J., Benzaid, S., Olsen, J., Smith, T., Steinberg, L., Sulman, J., Ritz, A., Anderson, B., Nelson, C., Musicant, D. R., Chen, L., Snyder, D. C., and Schauer, J. J.: Environmental chemistry through intelligent atmospheric data analysis, Environ. Modell. Softw., 25, 760-769, 2010.

Grover, B. D., Kleinman, M., Eatough, N. L., Eatough, D. J., Hopke, P. K., Long, R. W., Wilson, W. E., Meyer, M. B., and Ambs, J. L.: Measurement of total $\mathrm{PM}_{2.5}$ mass (nonvolatile plus semivolatile) with the Filter Dynamic Measurement System tapered element oscillating microbalance monitor, J. Geophys. Res., 110, D07S03, doi:10.1029/2004jd004995, 2005.

Gurjar, B. R., Jain, A., Sharma, A., Agarwal, A., Gupta, P., Nagpure, A. S., and Lelieveld, J.: Human health risks in megacities due to air pollution, Atmos. Environ., 44, 4606-4613, 2010.

Han, Y. M., Cao, J. J., Chow, J. C., Watson, J. G., An, Z. S., Jin, Z., Fung, K., and Liu, S.: Evaluation of the thermal/optical reflectance method for discrimination between char- and soot-EC, Chemosphere, 69, 569-574, 2007.

Han, Y. M., Cao, J. J., Lee, S. C., Ho, K. F., and An, Z. S.: Different characteristics of char and soot in the atmosphere and their ratio as an indicator for source identification in Xi'an, China, Atmos. Chem. Phys., 10, 595-607, doi:10.5194/acp-10-595-2010, 2010.

Heal, M. R., Naysmith, P., Cook, G. T., Xu, S., Duran, T. R., and Harrison, R. M.: Application of 14C analyses to source apportionment of carbonaceous $\mathrm{PM}_{2.5}$ in the UK, Atmos. Environ., 45, 2341-2348, 2011.

Healy, R. M., O’Connor, I. P., Hellebust, S., Allanic, A., Sodeau, J. R., and Wenger, J. C.: Characterisation of single particles from in-port ship emissions, Atmos. Environ., 43, 6408-6414, 2009.

Healy, R. M., Hellebust, S., Kourtchev, I., Allanic, A., O'Connor, I. P., Bell, J. M., Healy, D. A., Sodeau, J. R., and Wenger, J. C.: Source apportionment of $\mathrm{PM}_{2.5}$ in Cork Harbour, Ireland using a combination of single particle mass spectrometry and quantitative semi-continuous measurements, Atmos. Chem. Phys., 10, 9593-9613, 2010, http://www.atmos-chem-phys.net/10/9593/2010/.

Heintzenberg, J., Wiedensohler, A., Tuch, T. M., Covert, D. S., Sheridan, P., Ogren, J. A., Gras, J., Nessler, R., Kleefeld, C., 
Kalivitis, N., Aaltonen, V., Wilhelm, R. T., and Havlicek, M.: Intercomparisons and Aerosol Calibrations of 12 Commercial Integrating Nephelometers of Three Manufacturers, J. Atmos. Ocean. Tech., 23, 902-914, 2006.

Herich, H., Hueglin, C., and Buchmann, B.: A 2.5 year's source apportionment study of black carbon from wood burning and fossil fuel combustion at urban and rural sites in Switzerland, Atmos. Meas. Tech., 4, 1409-1420, doi:10.5194/amt-4-1409-2011, 2011.

Hoffer, A., Gelencsér, A., Guyon, P., Kiss, G., Schmid, O., Frank, G. P., Artaxo, P., and Andreae, M. O.: Optical properties of humic-like substances (HULIS) in biomass-burning aerosols, Atmos. Chem. Phys., 6, 3563-3570, doi:10.5194/acp-6-3563-2006, 2006.

Horvath, H.: Atmospheric light absorption-A review, Atmos. Environ.. Part A. General Topics, 27, 293-317, 1993.

Jacobson, M. Z.: Strong radiative heating due to the mixing state of black carbon in atmospheric aerosols, Nature, 409, 695-697, 2001.

Jeong, C.-H., Evans, G. J., Dann, T., Graham, M., Herod, D., Dabek-Zlotorzynska, E., Mathieu, D., Ding, L., and Wang, D.: Influence of biomass burning on wintertime fine particulate matter: Source contribution at a valley site in rural British Columbia, Atmos. Environ., 42, 3684-3699, 2008.

Jeong, C.-H., McGuire, M. L., Godri, K. J., Slowik, J. G., Rehbein, P. J. G., and Evans, G. J.: Quantification of aerosol chemical composition using continuous single particle measurements, Atmos. Chem. Phys., 11, 7027-7044, doi:10.5194/acp-11-70272011, 2011.

Kane, D. B., Oktem, B., and Johnston, M. V.: Nanoparticle Detection by Aerosol Mass Spectrometry, Aerosol Sci. Technol., 34, 520-527, 2001.

Lewis, K., Arnott, W. P., Moosmüller, H., and Wold, C. E.: Strong spectral variation of biomass smoke light absorption and single scattering albedo observed with a novel dual-wavelength photoacoustic instrument, J. Geophys. Res., 113, D16203, doi:10.1029/2007jd009699, 2008.

Maier, K. L., Alessandrini, F., Beck-Speier, I., Hofer, T. P. J., Diabate, S., Bitterle, E., Stoger, T., Jakob, T., Behrendt, H., Horsch, M., Beckers, J., Ziesenis, A., Hultner, L., and Frankenberger, M.: Health effects of ambient particulate matter - Biological mechanisms and inflammatory responses to in vitro and in vivo particle exposures, Inhal. Toxicol., 20, 319-337, 2008.

Maricq, M. M. and Xu, N.: The effective density and fractal dimension of soot particles from premixed flames and motor vehicle exhaust, J. Aerosol Sci., 35, 1251-1274, 2004.

Moffet, R. C. and Prather, K. A.: Extending ATOFMS Measurements To Include Refractive Index and Density, Anal. Chem., 77, 6535-6541, 2005.

Moffet, R. C. and Prather, K. A.: In-situ measurements of the mixing state and optical properties of soot with implications for radiative forcing estimates, Proc. Natl. Acad. Sci. USA, 106, 11872-11877, 2009.

Moffet, R. C., de Foy, B., Molina, L. T., Molina, M. J., and Prather, K. A.: Measurement of ambient aerosols in northern Mexico City by single particle mass spectrometry, Atmos. Chem. Phys., 8, 4499-4516, doi:10.5194/acp-8-4499-2008, 2008a.

Moffet, R. C., Qin, X., Rebotier, T., Furutani, H., and Prather, K. A.: Chemically segregated optical and microphysical properties of ambient aerosols measured in a single-particle mass spectrometer, J. Geophys. Res., 113, D12213, doi:10.1029/2007JD009393, 2008 b.

Müller, T., Henzing, J. S., de Leeuw, G., Wiedensohler, A., Alastuey, A., Angelov, H., Bizjak, M., Collaud Coen, M., Engström, J. E., Gruening, C., Hillamo, R., Hoffer, A., Imre, K., Ivanow, P., Jennings, G., Sun, J. Y., Kalivitis, N., Karlsson, H., Komppula, M., Laj, P., Li, S.-M., Lunder, C., Marinoni, A., Martins dos Santos, S., Moerman, M., Nowak, A., Ogren, J. A., Petzold, A., Pichon, J. M., Rodriquez, S., Sharma, S., Sheridan, P. J., Teinilä, K., Tuch, T., Viana, M., Virkkula, A., Weingartner, E., Wilhelm, R., and Wang, Y. Q.: Characterization and intercomparison of aerosol absorption photometers: result of two intercomparison workshops, Atmos. Meas. Tech., 4, 245-268, doi:10.5194/amt-4-245-2011, 2011.

Peltier, R. E., Weber, R. J., and Sullivan, A. P.: Investigating a Liquid-Based Method for Online Organic Carbon Detection in Atmospheric Particles, Aerosol Sci. Technol., 41, 1117-1127, 2007.

Petzold, A. and Schönlinner, M.: Multi-angle absorption photometry-a new method for the measurement of aerosol light absorption and atmospheric black carbon, J. Aerosol Sci., 35, 421-441, 2004.

Pratt, K. A., Hatch, L. E., and Prather, K. A.: Seasonal Volatility Dependence of Ambient Particle Phase Amines, Environ. Sci. Technol., 43, 5276-5281, 2009a.

Pratt, K. A., Mayer, J. E., Holecek, J. C., Moffet, R. C., Sanchez, R. O., Rebotier, T. P., Furutani, H., Gonin, M., Fuhrer, K., Su, Y., Guazzotti, S., and Prather, K. A.: Development and Characterization of an Aircraft Aerosol Time-of-Flight Mass Spectrometer, Anal. Chem., 81, 1792-1800, 2009b.

Qin, X., Bhave, P. V., and Prather, K. A.: Comparison of Two Methods for Obtaining Quantitative Mass Concentrations from Aerosol Time-of-Flight Mass Spectrometry Measurements, Anal. Chem., 78, 6169-6178, 2006.

Querol, X., Pey, J., Minguillón, M. C., Pérez, N., Alastuey, A., Viana, M., Moreno, T., Bernabé, R. M., Blanco, S., Cárdenas, B., Vega, E., Sosa, G., Escalona, S., Ruiz, H., and Artñano, B.: PM speciation and sources in Mexico during the MILAGRO-2006 Campaign, Atmos. Chem. Phys., 8, 111-128, doi:10.5194/acp8-111-2008, 2008.

Ramana, M. V., Ramanathan, V., Feng, Y., Yoon, S. C., Kim, S. W., Carmichael, G. R., and Schauer, J. J.: Warming influenced by the ratio of black carbon to sulphate and the black-carbon source, Nat. Geosci., 3, 542-545, 2010.

Reche, C., Querol, X., Alastuey, A., Viana, M., Pey, J., Moreno, T., Rodríguez, S., González, Y., Fernández-Camacho, R., de la Rosa, J., Dall'Osto, M., Prévôt, A. S. H., Hueglin, C., Harrison, R. M., and Quincey, P.: New considerations for PM, Black Carbon and particle number concentration for air quality monitoring across different European cities, Atmos. Chem. Phys., 11, 62076227, doi:10.5194/acp-11-6207-2011, 2011.

Reinard, M. S. and Johnston, M. V.: Ion Formation Mechanism in Laser Desorption Ionization of Individual Nanoparticles, J. Am. Soc. Mass Spectr., 19, 389-399, 2008.

Reinard, M. S., Adou, K., Martini, J. M., and Johnston, M. V.: Source characterization and identification by real-time single particle mass spectrometry, Atmos. Environ., 41, 9397-9409, 2007. 
Reisinger, P., Wonaschütz, A., Hitzenberger, R., Petzold, A., Bauer, H., Jankowski, N., Puxbaum, H., Chi, X., and Maenhaut, W.: Intercomparison of Measurement Techniques for Black or Elemental Carbon Under Urban Background Conditions in Wintertime: Influence of Biomass Combustion, Environ. Sci. Technol., 42, 884-889, 2008.

Riemer, N., Vogel, H., and Vogel, B.: Soot aging time scales in polluted regions during day and night, Atmos. Chem. Phys., 4, 1885-1893, doi:10.5194/acp-4-1885-2004, 2004.

Ruellan, S. and Cachier, H.: Characterisation of fresh particulate vehicular exhausts near a Paris high flow road, Atmos. Environ., 35, 453-468, 2001.

Sandradewi, J., Prévôt, A. S. H., Szidat, S., Perron, N., Alfarra, M. R., Lanz, V. A., Weingartner, E., and Baltensperger, U.: Using Aerosol Light Absorption Measurements for the Quantitative Determination of Wood Burning and Traffic Emission Contributions to Particulate Matter, Environ. Sci. Technol., 42, 33163323, 2008a.

Sandradewi, J., Prévôt, A. S. H., Weingartner, E., Schmidhauser, R., Gysel, M., and Baltensperger, U.: A study of wood burning and traffic aerosols in an Alpine valley using a multi-wavelength Aethalometer, Atmos. Environ., 42, 101-112, $2008 \mathrm{~b}$.

Sciare, J., Cachier, H., Oikonomou, K., Ausset, P., Sarda-Estève, R., and Mihalopoulos, N.: Characterization of carbonaceous aerosols during the MINOS campaign in Crete, July-August 2001: a multi-analytical approach, Atmos. Chem. Phys., 3, 1743-1757, doi:10.5194/acp-3-1743-2003, 2003.

Sciare, J., Cachier, H., Sarda-Estève, R., Yu, T., and Wang, X.: Semi-volatile aerosols in Beijing (R.P. China): Characterization and influence on various $\mathrm{PM}_{2.5}$ measurements, J. Geophys. Res., 112, D18202, doi:10.1029/2006JD007448, 2007.

Sciare, J., Oikonomou, K., Favez, O., Liakakou, E., Markaki, Z., Cachier, H., and Mihalopoulos, N.: Long-term measurements of carbonaceous aerosols in the Eastern Mediterranean: evidence of long-range transport of biomass burning, Atmos. Chem. Phys., 8, 5551-5563, doi:10.5194/acp-8-5551-2008, 2008.

Sciare, J., d'Argouges, O., Zhang, Q. J., Sarda-Estve, R., Gaimoz, C., Gros, V., Beekmann, M., and Sanchez, O.: Comparison between simulated and observed chemical composition of fine aerosols in Paris (France) during springtime: contribution of regional versus continental emissions, Atmos. Chem. Phys., 10, 11987-12004, doi:10.5194/acp-10-11987-2010, 2010.

Sciare, J., d'Argouges, O., Sarda-Estève, R., Gaimoz, C., Dolgorouky, C., Bonnaire, N., Favez, O., Bonsang, B., and Gros, V.: Large contribution of water-insoluble secondary organic aerosols in the region of Paris (France) during wintertime, J. Geophys. Res. Atm., 116, D22203, doi:10.1029/2011JD015756, 2011.

Shields, L. G., Suess, D. T., and Prather, K. A.: Determination of single particle mass spectral signatures from heavy-duty diesel vehicle emissions for PM2.5 source apportionment, Atmos. Environ., 41, 3841-3852, 2007.

Shields, L. G., Qin, X., Toner, S. M., and Prather, K. A.: Detection of Ambient Ultrafine Aerosols by Single Particle Techniques During the SOAR 2005 Campaign, Aerosol Sci. Technol., 42, 674-684, 2008.

Shiraiwa, M., Kondo, Y., Moteki, N., Takegawa, N., Miyazaki, Y., and Blake, D. R.: Evolution of mixing state of black carbon in polluted air from Tokyo, Geophys. Res. Lett., 34, L16803, doi:10.1029/2007GL029819, 2007.
Slowik, J. G., Cross, E. S., Han, J.-H., Davidovits, P., Onasch, T. B., Jayne, J. T., Williams, L. R., Canagaratna, M. R., Worsnop, D. R., Chakrabarty, R. K., Moosmüller, H., Arnott, W. P., Schwarz, J. P., Gao, R.-S., Fahey, D. W., Kok, G. L., and Petzold, A.: An Inter-Comparison of Instruments Measuring Black Carbon Content of Soot Particles, Aerosol Sci. Technol., 41, 295-314, 2007.

Snyder, D. C., Schauer, J. J., Gross, D. S., and Turner, J. R.: Estimating the contribution of point sources to atmospheric metals using single-particle mass spectrometry, Atmos. Environ., 43, 4033-4042, 2009.

Solomon, S., Qin, D., Manning, M., Alley, R. B., Berntsen, T., Bindo, N. L., Chen, Z., Chidthaisong, A., Gregory, J. M., Hegerl, G. C., Heimann, M., Hewitson, B., Hoskins, B. J., Joos, F., Jouzel, J., Kattsov, V., Lohmann, U., Matsuno, T., Molina, M., Nicholls, N., Overpeck, J., Raga, G., Ramaswamy, V., Ren, J., Rusticucci, M., Somerville, R., Stocker, T. F., Whetton, P., Wood, R. A., and Wratt, D.: IPCC: Climate Change 2007: The Physical Science Basis. Contribution of Working Group I to the Fourth Assessment Report of the Intergovernmental Panel on Climate Change, Cambridge University Press, UK, 2007.

Spencer, M. T. and Prather, K.: Using ATOFMS to Determine OC/EC Mass Fractions in Particles, Aerosol Sci. Technol., 40, 585-594, 2006.

Spencer, M. T., Shields, L. G., Sodeman, D. A., Toner, S. M., and Prather, K. A.: Comparison of oil and fuel particle chemical signatures with particle emissions from heavy and light duty vehicles, Atmos. Environ., 40, 5224-5235, 2006.

Stier, P., Seinfeld, J. H., Kinne, S., Feichter, J., and Boucher, O.: Impact of nonabsorbing anthropogenic aerosols on clearsky atmospheric absorption, J. Geophys. Res., 111, D18201, doi:10.1029/2006JD007147, 2006.

Stohl, A., Eckhardt, S., Forster, C., James, P., Spichtinger, N., and Seibert, P.: A replacement for simple back trajectory calculations in the interpretation of atmospheric trace substance measurements, Atmos. Environ., 36, 4635-4648, 2002.

Stohl, A., Forster, C., Frank, A., Seibert, P., and Wotawa, G.: Technical note: The Lagrangian particle dispersion model FLEXPART version 6.2, Atmos. Chem. Phys., 5, 2461-2474, doi:10.5194/acp-5-2461-2005, 2005.

Su, Y., Sipin, M. F., Furutani, H., and Prather, K. A.: Development and Characterization of an Aerosol Time-of-Flight Mass Spectrometer with Increased Detection Efficiency, Anal. Chem., 76, 712-719, 2003.

Sullivan, R. C. and Prather, K. A.: Recent advances in our understanding of atmospheric chemistry and climate made possible by on-line aerosol analysis instrumentation, Anal. Chem., 77, 38613885, 2005.

Szidat, S., Jenk, T. M., Synal, H.-A., Kalberer, M., Wacker, L., Hajdas, I., Kasper-Giebl, A., and Baltensperger, U.: Contributions of fossil fuel, biomass-burning, and biogenic emissions to carbonaceous aerosols in Zurich as traced by 14C, J. Geophys. Res., 111, D07206, doi:10.1029/2005JD006590, 2006.

Szidat, S., Ruff, M., Perron, N., Wacker, L., Synal, H.-A., Hallquist, M., Shannigrahi, A. S., Yttri, K. E., Dye, C., and Simpson, D.: Fossil and non-fossil sources of organic carbon (OC) and elemental carbon (EC) in Gteborg, Sweden, Atmos. Chem. Phys., 9, 1521-1535, doi:10.5194/acp-9-1521-2009, 2009.

Toner, S. M., Sodeman, D. A., and Prather, K. A.: Single Parti- 
cle Characterization of Ultrafine and Accumulation Mode Particles from Heavy Duty Diesel Vehicles Using Aerosol Timeof-Flight Mass Spectrometry, Environ. Sci. Technol., 40, 39123921, 2006.

Tuch, T. M., Haudek, A., Mller, T., Nowak, A., Wex, H., and Wiedensohler, A.: Design and performance of an automatic regenerating adsorption aerosol dryer for continuous operation at monitoring sites, Atmos. Meas. Tech., 2, 417-422, doi:10.5194/amt-2-417-2009, 2009.

UNEP: (United Nations Environment Programme) Integrated Assessment of Black Carbon and Tropospheric Ozone: Summary for Decision Makers, UNEP/GC/26/INF/20, UNEP, Kenya, 2011.

Wang, X. and McMurry, P. H.: A Design Tool for Aerodynamic Lens Systems, Aerosol Sci. Technol., 40, 320-334, 2006.

Weingartner, E., Saathoff, H., Schnaiter, M., Streit, N., Bitnar, B., and Baltensperger, U.: Absorption of light by soot particles: determination of the absorption coefficient by means of aethalometers, J. Aerosol Sci., 34, 1445-1463, 2003.

Wenzel, R. J., Liu, D.-Y., Edgerton, E. S., and Prather, K. A.: Aerosol time-of-flight mass spectrometry during the Atlanta Supersite Experiment: 2. Scaling procedures, J. Geophys. Res., 108, 8427, doi:10.1029/2001JD001563, 2003.
Whiteaker, J. R. and Prather, K. A.: Hydroxymethanesulfonate as a tracer for fog processing of individual aerosol particles, Atmos. Environ., 37, 1033-1043, 2003.

Yang, F., He, K., Ye, B., Chen, X., Cha, L., Cadle, S. H., Chan, T., and Mulawa, P. A.: One-year record of organic and elemental carbon in fine particles in downtown Beijing and Shanghai, Atmos. Chem. Phys., 5, 1449-1457, doi:10.5194/acp-5-1449-2005, 2005.

Yang, M., Howell, S. G., Zhuang, J., and Huebert, B. J.: Attribution of aerosol light absorption to black carbon, brown carbon, and dust in China - interpretations of atmospheric measurements during EAST-AIRE, Atmos. Chem. Phys., 9, 2035-2050, doi:10.5194/acp-9-2035-2009, 2009.

Zauscher, M. D., Moore, M. J. K., Lewis, G. S., Hering, S. V., and Prather, K. A.: Approach for Measuring the Chemistry of Individual Particles in the Size Range Critical for Cloud Formation, Anal. Chem., 83, 2271-2278, 2011. 